\title{
Trade Restrictions in Brazil : Who Pays the Price?
}

\author{
Sónia Araújo \\ OECD, Paris, France \\ Dorothee Flaig \\ OECD, Paris, France
}

\begin{abstract}
This study finds that a unilateral reduction in Brazil's relatively high barriers to trade would increase its integration into the world economy and expand production and jobs. Using a multi-region Computable General Equilibrium model that is particularly wellsuited to gauge the impact of trade policy shocks in global value chains, this study documents the effects of reducing important barriers to trade in Brazil: reducing import tariffs and local content requirements, and eliminating indirect taxes levied on exports. The largest gains in production and exports would accrue to manufacturing sectors, contradicting the widespread perception in Brazil that lifting trade protection would reduce the share of manufacturing in production. Moreover, deeper integration into global value chains would raise economic efficiency, and the higher share of foreign intermediate goods used in production would lead to lower prices, boost international
\end{abstract}

\footnotetext{
* Corresponding Author: Dorothee Flaig; OECD, 2, rue André Pascal - 75775 Paris Cedex 16, France. E-mail : Dorothee.FLAIG@ oecd.org. Tel: +33145249564. Fax: +33144306159

Co-Author: Sónia Araújo; OECD, 2, rue André Pascal - 75775 Paris Cedex 16, France. E-mail: sonia.araujo@oecd.org. Tel: +3314524 8301

Acknowledgements: The study develops from the OECD study: Araújo, S. and D. Flaig (2016), Quantifying the Effects of Trade Liberalisation in Brazil: A Computable General Equilibrium Model (CGE) Simulation, OECD Economics Department Working Papers, No. 1295, OECD Publishing, Paris. The CGE model employed in this study was developed by and for the OECD: OECD (2015), METRO version 1 model documentation, Trade and Agriculture Directorate, OECD, January.

This research did not receive any specific grant from funding agencies in the public, commercial, or not-for-profit sectors.
}

The opinions expressed and arguments employed herein are those of the authors and do not necessarily reflect the official views of the OECD or of the governments of its member countries. 
competitiveness, and also benefit Brazilian households.

JEL classifications: F13, F47, F61, F62, F66

Keywords: Trade Policy, Global Value Chains, Brazil, General Equilibrium Model

\section{Introduction}

The degree of openness of the Brazilian economy, measured as the sum of exports and imports over Gross Domestic Product (GDP), is small relative to that of other emerging market economies (Figure 1). Brazil's participation in Global Value Chains (GVCs), the defining feature of international trade and business in the past two decades, is low independent of the metric used: i) the share of foreign value-added content of exports is the second lowest among BRIICS (Brazil, Russia, India, Indonesia, China, and South Africa) countries, and it has not followed the common upward trend observed in developed and emerging economies alike; ii) the GVC participation index, measuring backward and forward participation in GVCs, is one of the lowest among emerging economies, and iii) about $65 \%$ of the value-added created in manufacturing GVCs is generated for the domestic market rather than for meeting the final demand abroad (OECD 2013, Reis and Almeida 2014). ${ }^{1}$

This study argues that reducing barriers to trade in Brazil could lead to stronger integration of the Brazilian economy into the global economy. Moreover, the study finds that the fear of premature deindustrialisation, the often-stated motivation for keeping some trade protection in place, is an unfounded one. Following trade liberalisation, production would increase in most sectors, but the largest gains in both production and exports would accrue to manufacturing. These are the conclusions of a simulation exercise gauging the impact on the overall economy of a unilateral reduction in barriers to trade. In order to depict the economy-wide spill-over effects, a multi-region Computable General Equilibrium (CGE) model is employed. Assessing the impact of

\footnotetext{
'Backward participation in GVCs refers to the share of foreign value-added in a given country's exports, while forward participation in GVCs measures the use of domestically produced inputs in third economies' exports. The GVC participation index is less correlated with the country size than the foreign value-added content of exports. For instance, the foreign content of United States' (US) exports is about $15 \%$, but US participation in GVCs rises to almost $50 \%$ when the use of US intermediates in other economies' exports is taken into account (OECD 2013).
} 
trade liberalisation is a policy question better answered by a CGE model, as they are able to track the impact of a policy change on the whole economy, identifying relative effects and understanding the adjustment path. An important contribution of the study rests in the particular CGE model used. The modelling framework allows disaggregating trade flows by the end use of the products traded. By being able to distinguish goods that are imported and exported for final versus intermediate consumption, the model is able to capture the integration of the Brazilian economy in global value chains and identify more appropriately the sources of gains from trade.

Similar to earlier works on Brazil, we find that trade liberalisation increases production, decreases domestic prices, and increases labour demand (Carneiro and Arbache 2003, Harrison et al. 2004). While Carneiro and Arbache (2003) find positive employment effects mainly amongst the most skilled workers in the most trade-oriented sectors, our results show, in line with Harrison et al. (2004), that employment increases in all labour categories, with the highest number of jobs being created in unskilled labour categories. In addition, about $50 \%$ of the new jobs are in the services sectors that are less trade related, that is, not subject to trade policies investigated in this study.

Harrison et al. (2004) simulate the impact of various trade agreement scenarios on poverty. They find that trade agreements help the poor and that Brazil could optimize outcomes by engaging in multilateral trade agreements. Our analysis focuses instead on gains accruing from an unilateral trade liberalisation, which could be seen as a more unfavourable approach for Brazil but relatively easier and quicker to implement to the extent that it does not involve international negotiations.

Moreover, this study adds to that of Harrison et al. (2004) as it addresses not only import tariffs but, similar to Carneiro and Arbache (2003), also evaluates the effects of trade protection on the export and import sides: i) import tariffs, ii) Local Content Requirements (LCRs), and iii) indirect taxes paid on exports.

The final contribution is of a more technical nature: While Harrison et al. (2004) base their study on extremely high trade elasticities, which are uncommon in the literature, this study provides a thorough sensitivity analysis to show the stability of the model outcomes to the choice of trade elasticities. 
Figure 1. The degree of openness of the Brazilian economy is small

(2016)

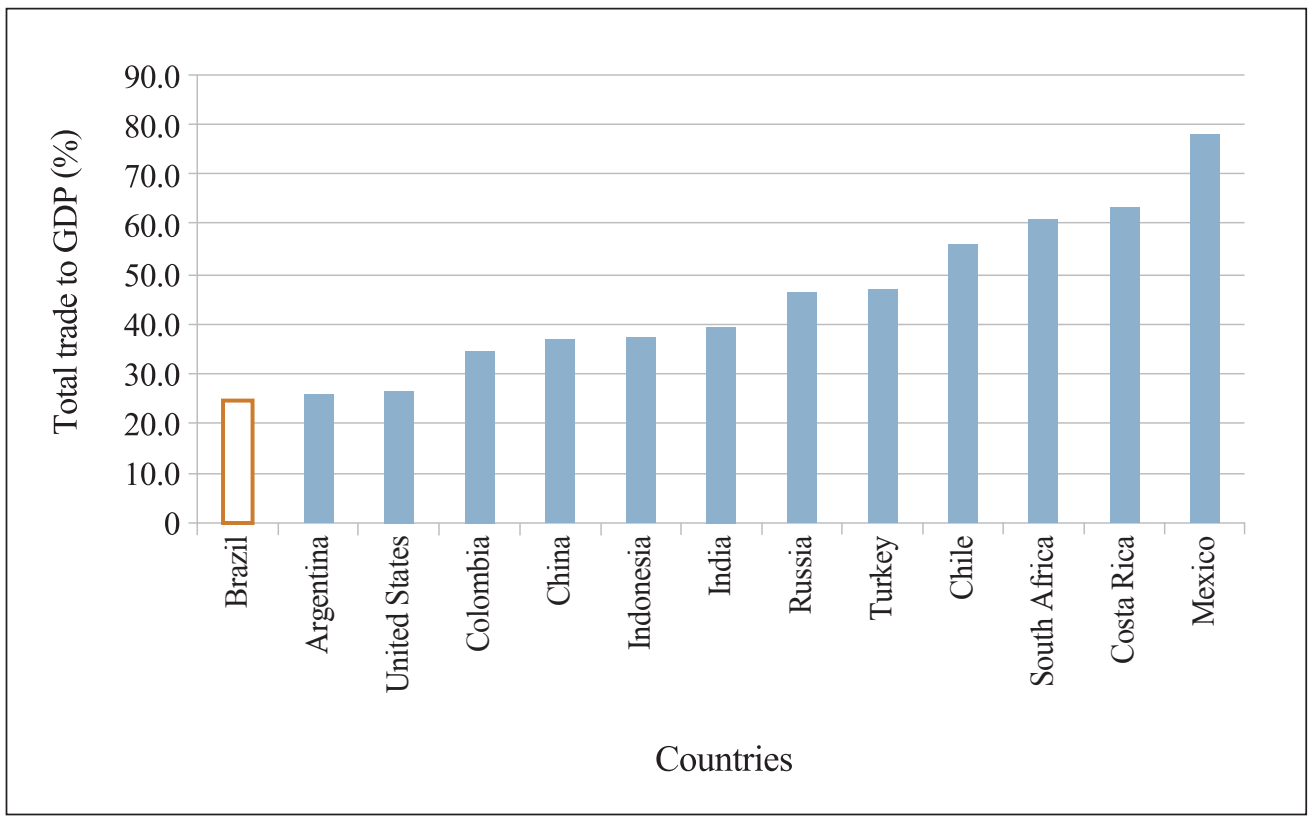

(Source) OECD Analytical (ADB) Database.

The remainder of this paper is structured as follows: Section II provides an overview of trade and tax policies that hamper the openness of the Brazilian economy and whose impact on the economy we simulate. Section III describes the policy change simulations and presents the model used in this study. Section IV discusses the effects of trade liberalisation on the economy. Section $\mathrm{V}$ tests the importance of macroeconomic assumptions and elasticity values on the results, and section VI concludes the paper with a final discussion of the outcomes.

\section{Brazilian Trade Policy}

Like in many other developing countries, international trade protection in Brazil has been employed traditionally as part of a strategy to promote industrial development. By restricting competition in the domestic market, policymakers sought to reduce 
the country's dependency on commodity exports, diversify production, and promote technological upgrades (Thorstensen and Ferraz 2015). A reform in 1991 put an end to a long period of important constraints, bringing down the modal tariff from $40 \%$ to $20 \%$ and the mean tariff from $42 \%$ in 1988 to $12 \%$ in 1994 . This tariff reform programme was accompanied by additional measures that greatly reduced the level of protectionism and opened up the Brazilian economy: Anexo C, a list of 1,300 products that in practice were not allowed to be imported, was eliminated alongside a majority of Special Regimes (Hay 1997).

Since 1994, import tariffs in most sectors have averaged around $10 \%$ to $20 \%$, after having fallen from very high levels in some sectors, for instance, from $90 \%$ to $20 \%$ in wearing apparel and from $48 \%$ to $14 \%$ in machinery and equipment. However, products with higher technological content (software and fine chemicals), longer production chains (automobiles), or low competitiveness relative to products from Asian economies (consumer electronics) are subject to higher tariff rates of between $30 \%$ to $35 \%$. Subsequently, there have been several small occasional amendments, including tariff hikes for many products included in the Mercosur list of exceptions (capital goods, computing, and telecommunications) in 1995, a generalised increase of 3\% in 1997, and a temporary tariff increase for 100 products in 2012 (Hay 1997, Castilho et al. 2015). As of 2004, two indirect taxes began to be levied on imports, whereas before they were only levied on domestic production (Baumann and Kume 2013). ${ }^{2}$ Today's tariff profile is not much different from the one resulting from the tariff reform programme of 1991 and Mercosur negotiations. Overall, despite substantial trade liberalisation in the 1990s, traces of the Brazil import-substitution industrialisation strategy still remain.

Among BRICS countries, Brazil applies the highest mean import tariff on nonagricultural products and the second highest overall (Thorstensen and Ferraz 2015). In 2014 , the mean non-weighted tariff was $11.7 \%$ and the maximum was $55 \%$, albeit applied to only two products. The second highest tariff rate is $35 \%$, applied to about 500 products across several sectors, predominantly in textiles and automotive vehicles. The modal tariff was 14\% and the median 12\% (Castilho et al. 2015). At the sector level, Brazil applies tariffs above $10 \%$ in textiles, wearing apparel, leather, wood products, ferrous metals, motor vehicles, machinery and equipment, and other manufacturing (weighted averages). Other manufacturing sectors have tariffs between 5\% and 10\%. There are no or small import tariffs below $2 \%$ applied to coal, oil, gas, minerals, and

\footnotetext{
These taxes are the "Contribuição para Financiamento da Seguridade Social" (Cofins) and the "Programa de Integração Social/ Programa de Formação do Patrimônio do Servidor Público" (PIS/PASEAP).
} 
petrochemical products. As regards bilateral trade policy, Brazil has adopted a strategy of regional integration, and it has lowered trade barriers against other Latin American economies through preferential agreements offering tariff reductions, while maintaining higher protection against other regions.

Brazil is also imposing LCRs on an increasing number of products (Mattos 2013). LCRs are demands made to a firm or sector to purchase domestically a given share of inputs or goods and services for investment purposes. LCRs fall under the larger category of so-called "localisation barriers" to trade that favour domestic industry at the expense of foreign competitors. LCR measures are put in place largely with a view to support industrial and technological development and the associated employment gains they purportedly bring (OECD 2014). Studies assessing the impact of LCRs have generally concluded that although these policies may achieve some of their short-run objectives, they undermine industrial competitiveness over the long run (Hufbauer 2013). An OECD study finds that Brazil is second only to Indonesia in the number of LCRs imposed since the onset of the global crisis in 2008 (OECD 2014). The study documents 17 LCRs in force in Brazil: nine concerning input measures, six involving government procurement, and two imposing ownership/local partnership obligations. We simulate the effects of lifting LCRs restricting market access and LCRs involving price preference measures but do not include LCRs on government procurement, as they are not so readily modelled in METRO, the OECD CGE Trade Model used in our study.

In contrast to the generalised international practice on indirect taxation, Brazilian exports are not zero taxed. In spite of a Constitutional amendment (No. 42/2003) exempting exports from indirect taxes, in practice, administrative hurdles and limiting instruments, including those provided for in the Lei Kandir and in individual state legislation, prevent exporters from recovering indirect taxes levied along the production chain (de Siqueira et al. 2010, Vieira and Mourão 2015). Although indirect taxes are not listed among trade impediments, their sheer size and the difficulty of Brazilian entrepreneurs in obtaining a zero rating for exports puts them at a competitive disadvantage with foreign competitors in international markets, constituting a de facto barrier to trade.

Indirect taxes tend to be lower on agricultural and food products compared with manufactured goods, which involve longer production chains and tend to accumulate more indirect taxes relative to products with little or no transformation. Different 
indirect (ICMS) ${ }^{3}$ tax rates applied to different products and cumulative taxation lead to severe distortion of relative prices that in turn causes important resource misallocation, with resources shifting away from manufacturing into raw materials and agribusiness (OECD 2015a). In addition, this incentivises businesses to vertically integrate production stages into a single firm, which is likely to bring inefficiencies and is in contrast with today's organisation of production in value-chains (Mendes 2014). Finally, it directs final consumption towards relatively cheaper imported goods, which are not subject to cumulative taxation in their country of origin.

Protection of the domestic market through import tariffs and LCRs reduces the incentives to raise efficiency and invest in innovation to increase quality or product differentiation. In addition, it prevents domestic producers from sourcing from the lowest-cost or high-quality input suppliers. Failing to zero-tax exports increases producer prices, setting Brazilian exports at a competitive disadvantage relative to international competitors. Today, Brazil's GDP represents more than 3\% of the world economy, but its export market share is around $1.2 \%$, a figure that has remained almost unchanged in the past two decades (Figure 2). Despite the high level of protection, the industry share in total value-added has been unchanged in the past 20 years, and Brazil's industrial sector is actually small for a middle-income economy (Figure 3). Moreover, the share of manufacturing in total value-added has actually declined in the past 10 years, while labour productivity in manufacturing has stayed constant at very low levels (Figure 4, OECD 2015a).

\footnotetext{
${ }^{3}$ Imposto sobre Operações relativas à Circulação de Mercadorias e Prestação de Serviços de Transporte Interestadual e Intermunicipal e de Comunicação
} 


\section{Figure 2. Brazil's share of world trade is low relative to its GDP}

(Brazil's share of world income, exports and imports)

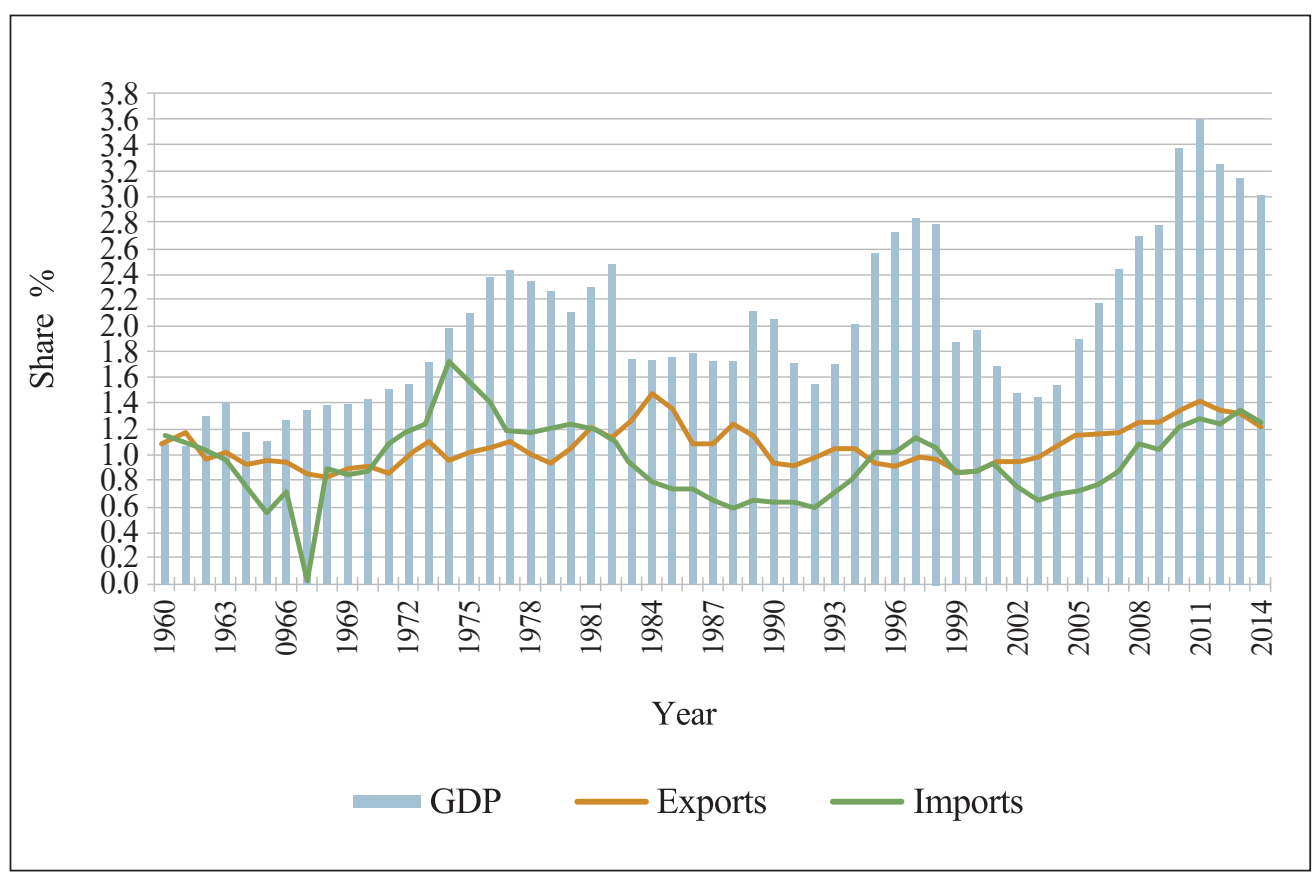

(Source) Secretaria de Comércio Exterior (SECEX) do Ministério do Desenvolvimento, Indústria e Comércio Exterior (MDIC), World Bank Development Indicators. 
Figure 3. Brazil's industrial sector is small for an upper middle-income country

(2012)

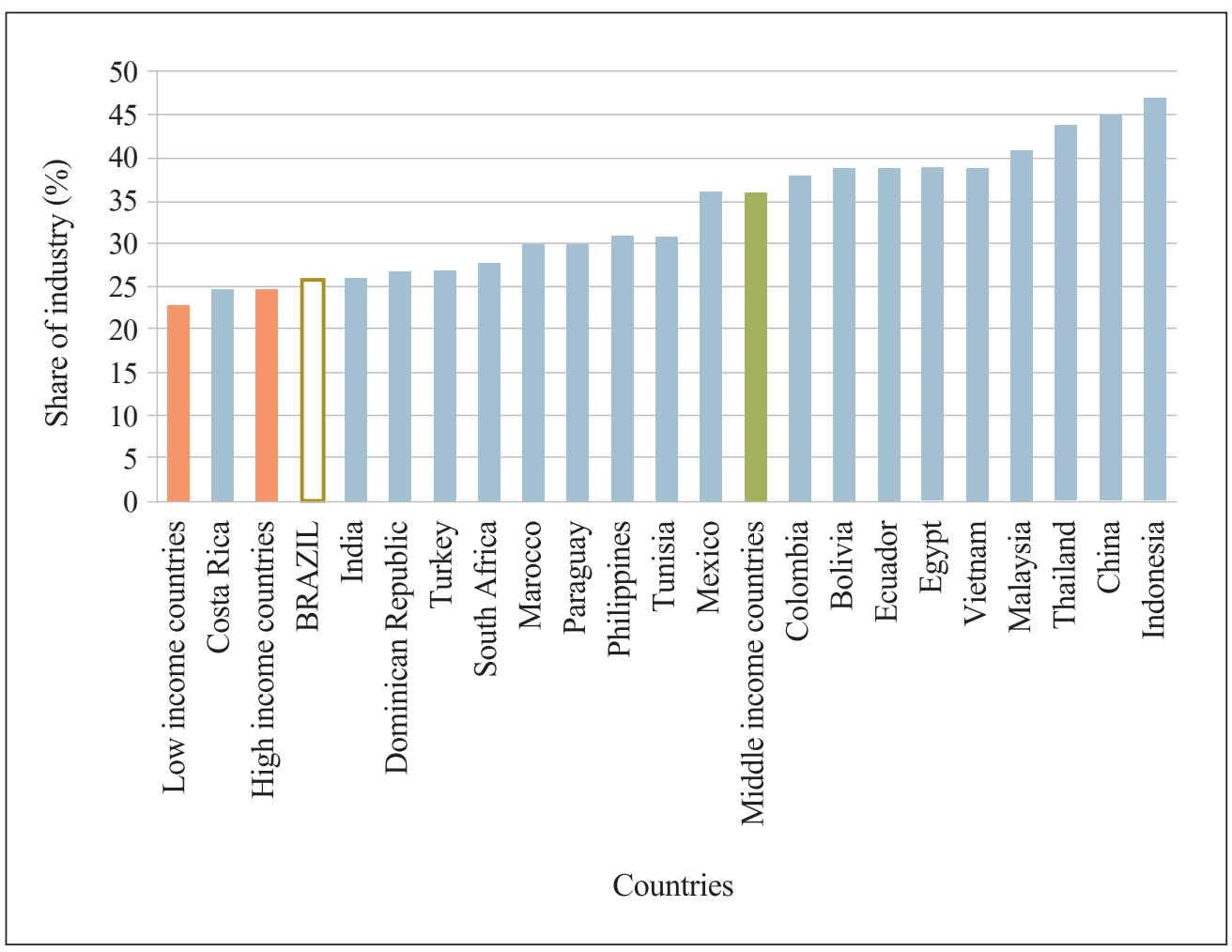

(Note) Share of industry in total value added in middle-income countries, in per cent, 2012.

(Source) World Bank. 


\section{Figure 4. Manufacturing productivity is low and stagnant}

(in thousands of constant 2005 US dollars per employee)

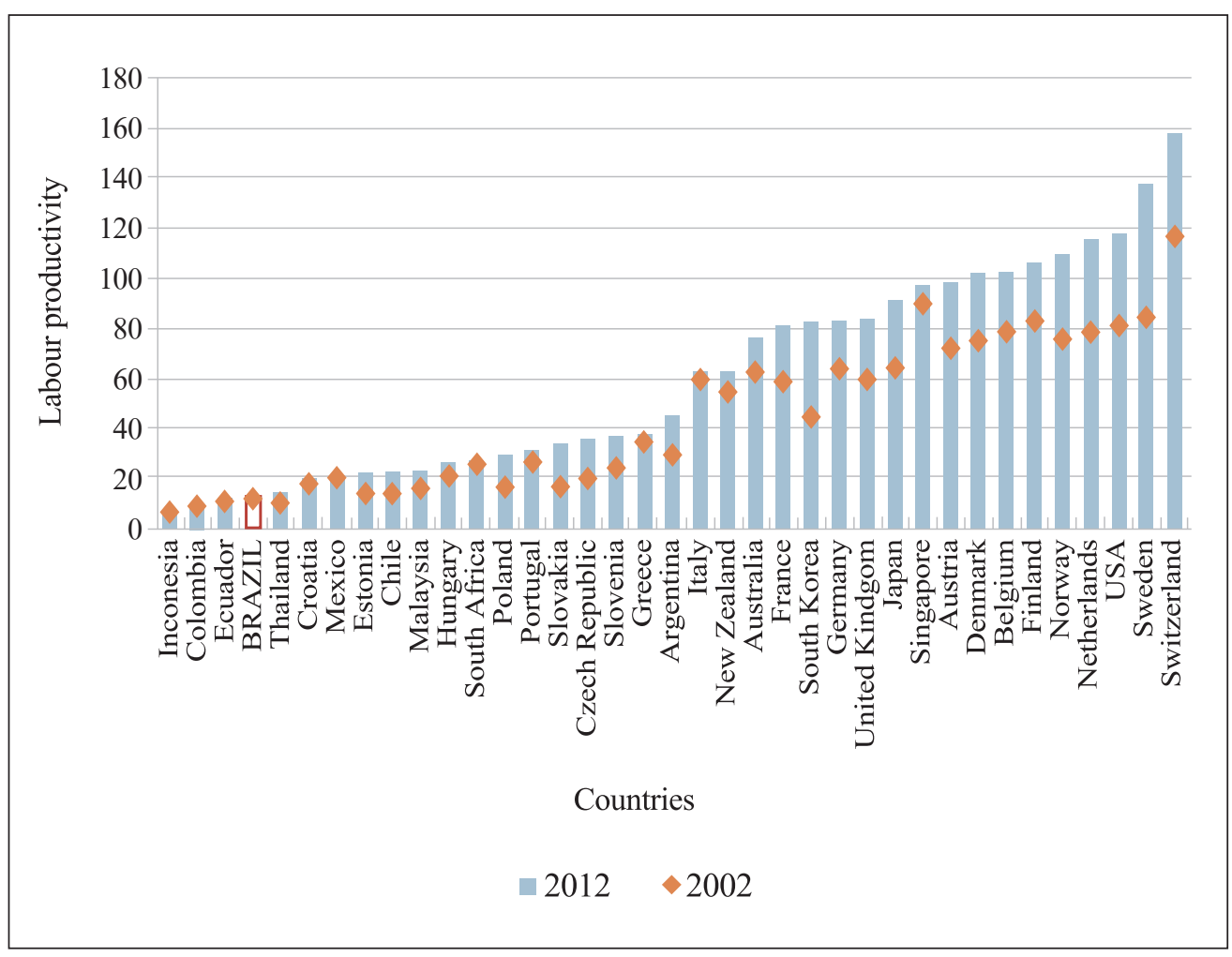

(Source) World Bank, ILO, Instituto Brasileiro de Geografia e Estatística (IBGE).

\section{Simulation}

\section{A. Policy scenarios}

The simulations intend to evaluate the economic impact of lifting or reducing trade policies that hinder the integration of the Brazilian economy in the world economy: import tariffs, LCRs, and taxes levied on exports, which, in the Brazilian case, stem mostly from non-zero-rating of exports in indirect taxes. As LCRs that are part of this 
simulation constitute only a subset of the total LCRs in the Brazilian economy, ${ }^{4}$ their impact is simulated together with import tariffs. In total, four simulations scenarios are run, combining different sets and sizes of policy shocks:

- OECD minimum import tariffs and no LCRs: This involves a reduction of import tariffs on all goods to the minimum levels applied in OECD countries and elimination of sector-specific LCRs. This scenario roughly corresponds to Brazil applying the low tariff rates of Switzerland and Norway on industrial goods and those of Australia and New Zealand to agriculture and the food industry.

- OECD minimum tariffs on imports of intermediate goods and no LCRs: This involves a reduction of import tariffs on goods used in downstream production processes to the minimum levels applied in OECD countries and elimination of sector-specific LCRs, while maintaining tariffs on goods destined for final consumption. This scenario implies that Brazil adopts the tariff rates of Switzerland and Norway on industrial goods used in intermediate stages of production and those of Australia and New Zealand for agriculture and the food industry. Focusing on barriers to intermediate goods alone allows identifying the impact on the competitiveness of domestic production and hence exports.

- Zero rating of exports in indirect taxes: Brazil applies export taxes narrowly, but, in effect, exports are subject to indirect taxes. This scenario effectively simulates the effect of eliminating indirect taxes levied on exports.

- Full liberalisation: This scenario comprises a simultaneous reduction of all import tariffs to the minimum level applied in OECD countries, eliminating sectorspecific LCRs and applying zero rating of exports.

Data on import tariffs and taxes on exports are based on the Global Trade Analysis Project (GTAP) version 8 database, which draws on the MacMap database of the International Trade Centre (ITC). ${ }^{5}$ Trade flows are distinguished by end-use category into intermediate goods and consumption goods using the OECD BTDIXE 2013 edition for manufacturing and agricultural sectors and the OECD Inter-Country Input-Output Model (May 2013) for the services sectors. Information on LCRs is sourced from

\footnotetext{
${ }^{4}$ The quantitative analysis presented in this paper follows the approach of the aforementioned OECD study on the worldwide effects of LCRs (OECD 2014), which restricts the analysis of LCRs in the areas of market access and price preference measures; this includes seven LCRs in Brazil.

${ }^{5}$ See Narayanan et al. (2012). Tariffs are weighted averages of bilateral tariffs applied at the HS6 product level.
} 
OECD (2014).

\section{B. The METRO model}

This study makes use of the OECD Trade Model, METRO, ${ }^{6}$ which derives from the Social Accounting Matrix (SAM) based CGE model GLOBE developed by McDonald and Thierfelder (2013). METRO is a multi-region CGE model that captures interindustry effects while tracking differences in trade patterns by individual country and sector.

The general equilibrium setup of CGE models, including the whole economy, makes it possible to detect spill-over effects and allow for the analysis of effects on various economic variables such as trade, production, or final demand. Therefore, CGE models are typically used to evaluate policy shocks whose impacts are expected to be complex, are transmitted by different channels, have economy-wide effects, and materialise not only in one but various rounds (e.g., trade and fiscal policy reform). They are especially useful to answer "what-if" type of questions. By nature, CGE models also include numerous parameters, that is, elasticities, which are often criticised. To account for these criticisms and evaluate the effects of various assumptions on the results, the study contains a section on sensitivity analysis.

Similar to any CGE model, METRO requires a complete specification of all economic activities and explicit recognition of inter-sector linkages. This approach is therefore ideal for examining the impact of a change in policy on the whole economy. The novelty and strength of the OECD Trade Model lies in the disaggregation of imports based on use categories - commodities and thus trade flows are distinguished by use category into commodities destined for intermediate use, use by households, government consumption as well as investment commodities - as opposed to the widely applied proportionality assumption. This feature makes METRO particularly well-suited to analyse global value chains.

METRO uses a database based on the GTAP database, version 8, with the base year of 2007. The database consists of 57 sectors, 56 country/regions, and four factors of production, with labour further disaggregated into five groups according to skill level. For the purpose of this study, several commodity sectors are aggregated into

\footnotetext{
${ }^{6}$ For a detailed description of the model, please see OECD (2015b).
} 
the Agriculture and Food sectors, and trading partners are allocated to seven regions (Appendix 1). In addition, the model uses a vector of trade and production elasticities, which are based on GTAP elasticities. For the purpose of this study, the chosen trade elasticities are double the standard GTAP values; the reasons for this choice and a thorough sensitivity analysis are included in the section $\mathrm{V}$.

Like GLOBE, the underlying approach in the METRO multi-region model is the construction of a series of single-country CGE models that are linked through trade relationships. As is common in CGE models, the price system is linear homogeneous, which implies that simulations provide relative, not absolute, price changes. Each region has its own numéraire, typically the Consumer Price Index (CPI), and an exchange rate (an exchange rate index of reference regions serves as model numéraire). Thus, price effects inside a country are fed through the model as a change relative to the country's numéraire, and prices between regions change relative to the reference region. Imports compete with domestic goods, and producers' decisions to export are based on relative price differentials between domestic and foreign markets.

On the production side, the model assumes perfect competition and constant returns to scale. Production activities maximise profits and form output from primary inputs (i.e., land, natural resources, labour, and capital), combined using the Constant Elasticity of Substitution (CES) technology, and intermediate inputs in fixed shares (Leontief technology). Households are assumed to maximise utility subject to the Stone-Geary utility function, which allows for the inclusion of a subsistence level of consumption. All commodity and activity taxes are expressed as ad valorem tax rates, and taxes are the only income source to the government. Government consumption is in fixed proportion to its income, and government savings are defined as residual. Closure rules for the government account allow for various fiscal specifications. ${ }^{7}$ Total savings consist of savings from households, the internal balance on the government account, and the external balance on the trade account. The external balance is defined as the difference between total exports and total imports in domestic currency units. While income to the capital account is defined by several savings sources, expenditures by the capital account are based solely on commodity demand for investment.

\footnotetext{
7 The default assumption for the government account is a fixed internal balance and fixed government expenditures. Income tax is variable to clear the government account. Similarly, any of the other tax rates could be set free to balance the government account. Alternatively, to the volume of government demand, the government share of final demand or the value of government expenditure could be fixed. Another setting could assume, for example, a flexible internal balance and fixed tax rates.
} 


\section{Underlying economic conditions}

CGE models resemble a closed system of economic flows, and markets must be balanced. The so-called closure rules specify how markets balance. METRO allows for several general closure rules that relate to macroeconomic considerations (e.g., if investment is savings driven or exogenous) and specific closure rules that capture particular features of an economic system (e.g., the degree of intersectoral capital mobility).

The medium-long term standard closure is specified as the following:

- Following the standard norm, in the foreign exchange market, the current account balance is fixed in the standard closure, and the exchange rate is floating. This assumption avoids the giving or bouncing of welfare effects to the rest of the world. In a comparative static model, the country otherwise would have the possibility to indefinitely run a balance of trade deficit without having to pay it back. The model is governed by relative price changes, and the exchange rate index for the reference region (North America) serves as the world numéraire and the region-specific consumer price index serves as the regional numéraire.

- In the capital market, the model setup follows the Keynesian approach with investment-driven savings, so that the value of investment remains as a fixed share of final demand, and the savings rate adjusts.

- Governments are assumed to maintain a constant spending relative to final demand, and the tax rates adjust to maintain the balance. In this exercise, income tax revenues adjust to maintain the balance.

- In factor markets, capital, land, and natural resources are fully employed and mobile across sectors. Labour is assumed mobile across sectors, and there is unemployment. The sensitivity of results to these underlying assumptions about the behaviour of the economy is tested by re-running the policy simulations and allowing each of the following macroeconomic conditions to change at a time:

- Assuming a fixed exchange rate and a flexible current balance

- Assuming full employment

- Assuming savings-driven investment where household savings determine the investment level

- Assuming that governments receive a fixed revenue amount and adjust expenditures to balance the budget 


\section{Effects of the Brazilian Trade Policy}

All policy measures towards liberalising trade would raise aggregate exports, production, employment, investment, and households' income and consumption (Table 1 and Table 2). The largest gains on production accrue from ending indirect taxation of exports. Total exports would be about 19\% higher in the absence of all trade barriers, including LCRs and input taxes on exports.

\section{A. International trade}

Table 1. Macroeconomic impact of removing barriers to trade in Brazil

(\% change to the base)

\begin{tabular}{|l|c|c|c|c|c|}
\hline & \multicolumn{5}{|c|}{ Simulated Policy Scenarios } \\
\hline $\begin{array}{c}\text { Impact on main } \\
\text { macroeconomic } \\
\text { aggregates: }\end{array}$ & $\begin{array}{c}\text { OECD } \\
\text { minimum } \\
\text { import tariffs } \\
\text { on intermediate } \\
\text { goods and no } \\
\text { LCRs }\end{array}$ & $\begin{array}{c}\text { OECD } \\
\text { minimum } \\
\text { import tariffs } \\
\text { and no LCRs }\end{array}$ & $\begin{array}{c}\text { Zero } \\
\text { rating of } \\
\text { exports }\end{array}$ & $\begin{array}{c}\text { Full } \\
\text { liberalisation }\end{array}$ & $\begin{array}{c}\text { Initial value } \\
(2008, \text { in billion } \\
\text { US dollars) }\end{array}$ \\
\hline Exports & 7.69 & 11.70 & 5.88 & 18.75 & 179.18 \\
\hline Intermediates & 6.16 & 10.79 & 5.65 & 17.55 & 126.70 \\
\hline Household consumption & 7.55 & 10.97 & -0.14 & 10.93 & 52.48 \\
\hline Imports & 8.28 & 12.80 & 6.06 & 19.98 & 161.08 \\
\hline Intermediates & 14.25 & 10.02 & 6.27 & 17.44 & 118.71 \\
\hline Household consumption & -6.29 & 15.81 & 6.22 & 23.43 & 42.37 \\
\hline Household Income & 0.69 & 0.70 & 0.83 & 1.62 & 938.95 \\
\hline Production & 0.62 & 0.41 & 1.16 & 1.74 & 2355.68 \\
\hline Investment & 0.59 & 1.05 & 0.99 & 2.13 & 241.70 \\
\hline Labour demand & 0.61 & 0.53 & 0.89 & 1.53 & \\
\hline Investment Price Index & -0.40 & -1.12 & -0.41 & -1.59 & \\
\hline Producer Price Index & -0.08 & 0.00 & -0.03 & -0.03 & \\
\hline
\end{tabular}

(Note) 'Full liberalisation' combines two scenarios: “OECD minimum import tariffs and no local content requirements (LCRs)" and "Zero rating of exports".

(Source) Model results. 
The largest contribution to export growth stems from the lower tariffs on intermediate goods used in production of goods and services in Brazil, signalling a gain in competitiveness due to cheaper imported inputs. ${ }^{8}$ The total effects on exports are larger than increases in exports for intermediate use and household consumption, which account for $70 \%$ and $18 \%$ of exports, respectively, due to an increase in capital goods exports, which account for an additional $10 \%$ of total export growth.

The boost in exports of intermediate goods and services (Table 1, third row) and exports for final consumption (Table 1, fourth row) are approximately of the same magnitude when import protection is reduced (i.e., a cut in tariffs and LCRs), while zero-taxing exports would mainly have an impact on raising exports of intermediate goods and services. This result is driven by the current structure of Brazilian trade and hence by the static nature of the model. More than half of final consumption exports are comprised of agriculture and food products, which benefit from no or very low ICMS tax rate, the largest indirect tax. Instead, nearly $70 \%$ of exports of intermediate goods are manufactured goods, characterised by longer production chains, hence tending to accumulate more indirect taxes along the production process.

The rise in exports is greater than the rise in imports in all policy scenarios. Tariff cuts and the removal of LCRs lead to an increase in imports as a direct effect, but second-round effects mitigate this inflow: the reduction of import barriers to trade decreases input prices for domestic producers, lowering production costs and increasing competitiveness. However, the clear net effect is not robust to changes in the model elasticities.

\section{B. Effects on production}

A liberalisation of Brazil's trade increases overall production. The largest effect in terms of individual policies comes from zero-taxing exports, but the reduction of tariff on intermediate goods and LCRs has an important positive effect on production as well. When all trade restrictions considered in this exercise are removed, production increases by $1.7 \%$ (Table 1 ).

The protection of the domestic market often comes from the belief that increased openness destroys jobs and increases low Value Added (VA) exports while importing

\footnotetext{
${ }^{8}$ Recall that the scenario "OECD minimum imports tariffs and no LCRs" implies the elimination of all import taxes, including those levied on intermediate goods.
} 
high VA products. Brazil's current export structure is strongly concentrated: five sectors account for more than $50 \%$ of total exports, and agricultural, mining, and gas exports alone account for 35\% (Figure 5A). Our results reveal that full trade liberalisation increases exports in all sectors except oil and gas, with the strongest gains occurring in manufacturing, shifting export concentration away from primary products (Figure 7 and Appendix 3). Moreover, the largest export increases include high value-added sectors wherein production is undertaken in global production chains (increases between $35 \%$ and $62 \%$ ): these include leather products, electronic equipment, transport equipment, motor vehicles, ferrous and other metals, and machinery and equipment sectors. Consequently, the share of primary goods exports in total exports decreases by six percentage points to $32 \%$. Exports even increase to all regional partners.

\section{Figure 5. Export and import structure of Brazil}

\section{A. Exports}

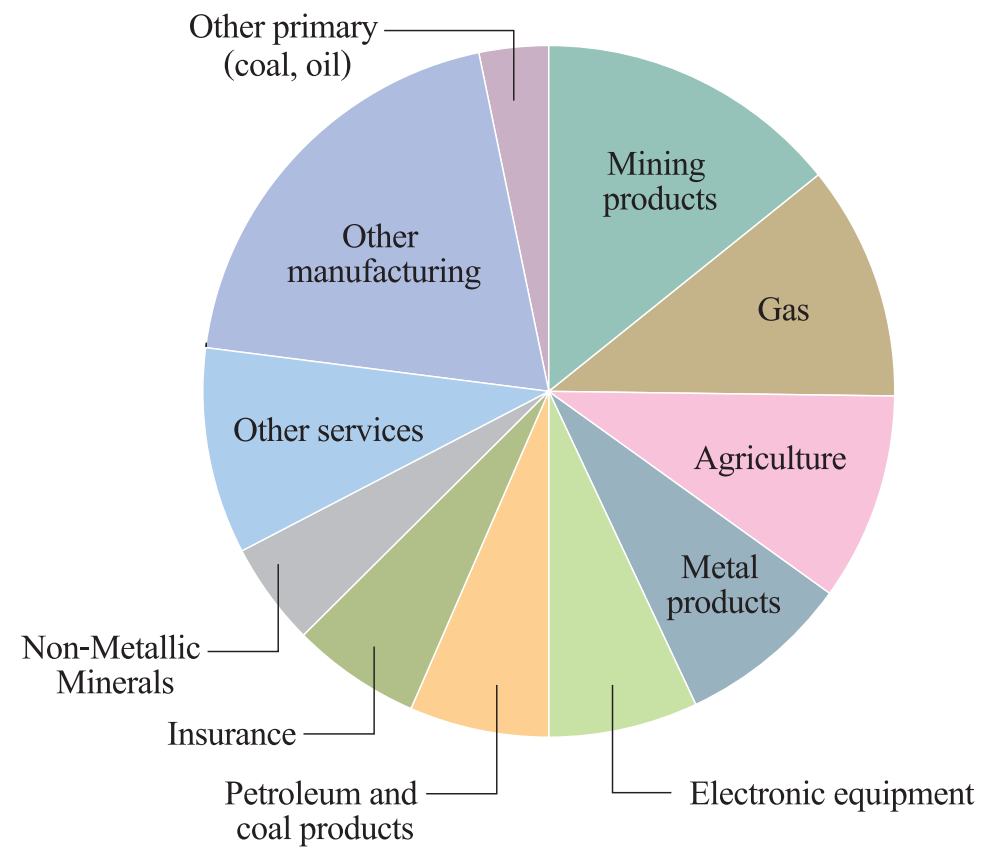




\section{B. Imports}

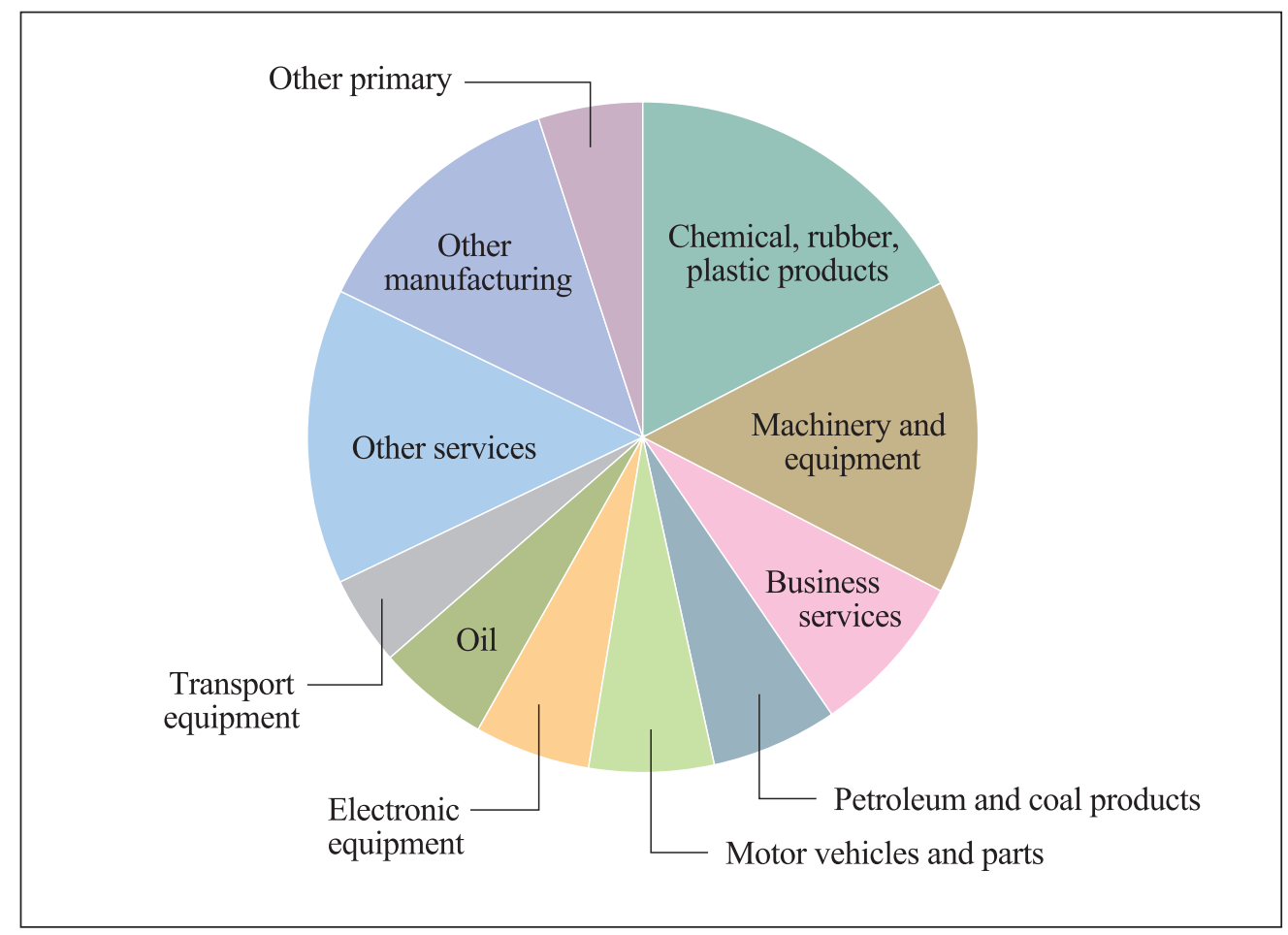

(Source) METRO database (year 2008).

Similar to exports, imports are strongly concentrated in a few sectors: chemicals, rubber, plastic products, and machinery and equipment alone account for $33 \%$ of the total imports (Figure 5B). Import liberalisation has two opposite effects on production: On one hand, firms benefit from access to cheaper inputs. This effect is most prominent in metal products, transport equipment, and leather products, where production is increased in simulations that only consider import liberalisation (Appendix 2). On the other hand, firms face increasing competition in final demand and intermediates, and, indeed, production decreases in textiles, chemical, rubber, plastic products, and machinery and equipment. The negative effect seems only partly related to the import share or level of initial protection, depending as well on whether production can benefit from decreasing production costs. For example, while non-ferrous metals are strongly imported (import share of $37 \%$ ) and wood products are strongly protected with average tariff levels around $15 \%$, both sectors benefit from import liberalisation and increase production (Appendix 2).

All sectors benefit from the full liberalisation of trade, and the effect is strongest in 
manufacturing production with a $2.5 \%$ increase (Figure 6). Primary sectors benefit more from import liberalisation, and manufacturing sectors benefit more from the liberalisation of the export side. Total production is slightly negatively affected when all import tariffs and LCRs are eliminated. However, when exports are exempted from indirect taxes, manufacturing experiences an additional positive boost from tariff reduction (Figure 6). Services benefit from reduction of trade restrictions on both the import and export sides. Figure 7 shows how different sectors contribute to the overall trade and how production increases with full liberalisation.

Figure 6. Effects on production

(\% change to base)

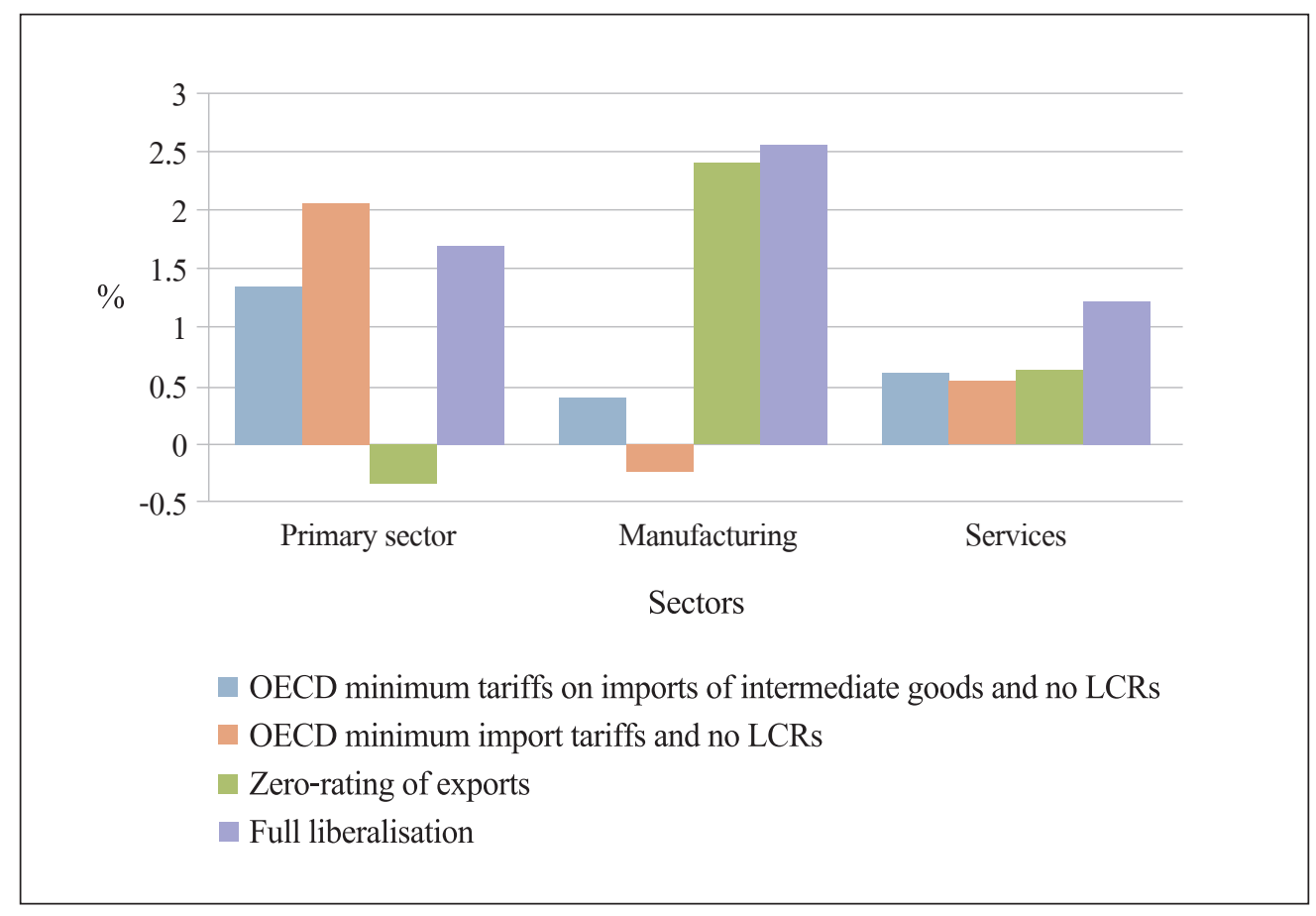

(Source) Model results. 
Figure 7. Effects of full liberalisation on production, imports and exports:

(Contributions by sector)
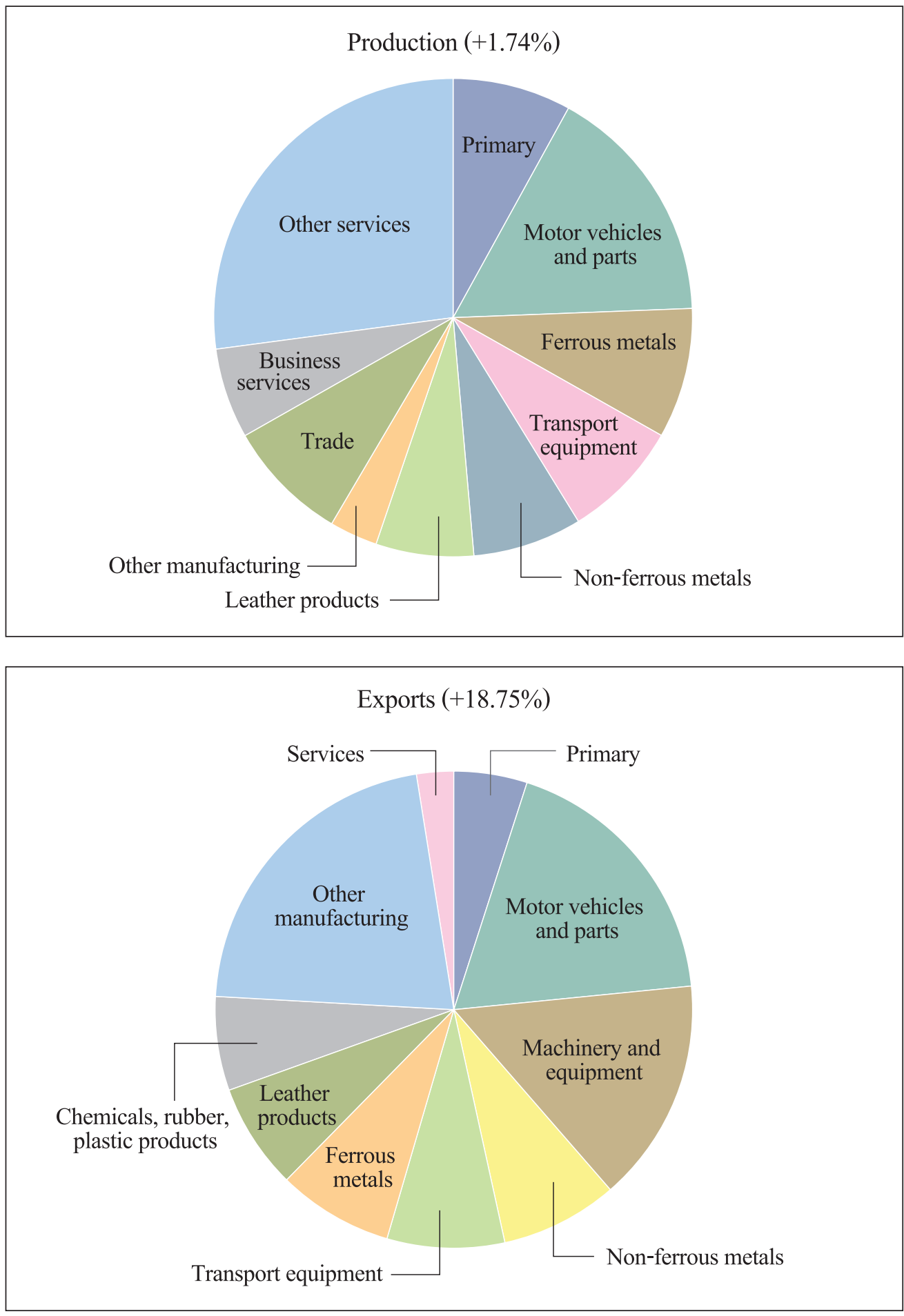


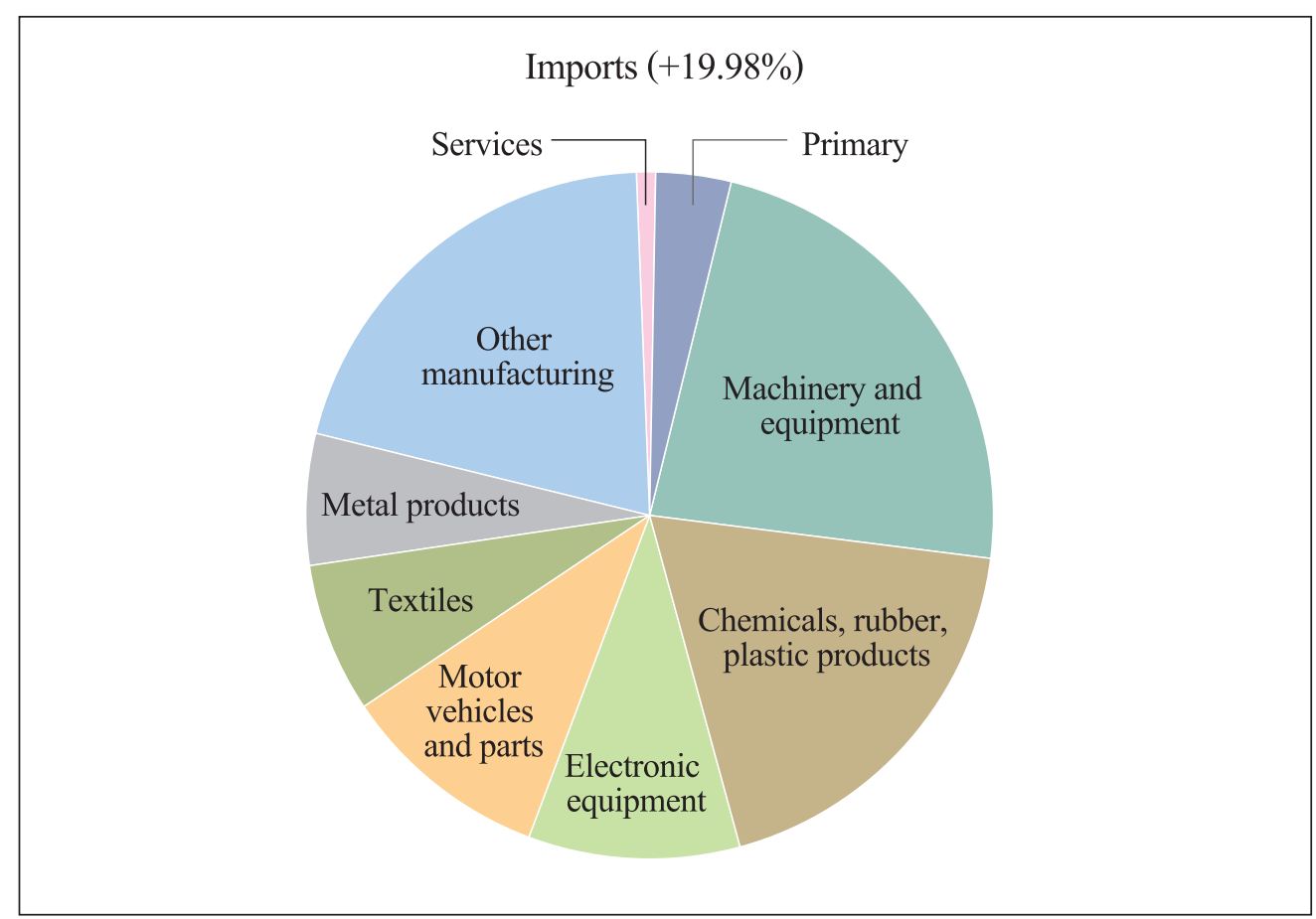

(Note) Sectoral contribution to overall trade and production effects under the full liberalisation scenario. The 7 largest contributors are detailed, others aggregated in large sector categories.

(Source) Model results.

The expansion of economic activity is supported by increased investment, which rises by $0.6 \%$ to more than $2.1 \%$, depending on whether only tariffs on intermediate goods imports are abolished or all other barriers curbing trade are dismantled, and lower import tariffs reduce the unitary cost of investment (investment price index).

\section{Effects on employment and private consumption}

Liberalising trade flows would raise employment by 1.47 million. All labour categories would benefit from increased employment in all policy simulations (Table 2). Moreover, employment increases are relatively large for agricultural and other lowskilled workers and the two skilled labour categories. Full liberalisation increases employment in these categories by about $1.3 \%$. As the economy expands, employment effects are positive but smaller in labour categories that are predominantly employed in service sectors, such as service shop workers and clerks. 
Table 2. Employment effects

( $\%$ change and increase in the number of workers)

\begin{tabular}{|c|c|c|c|c|}
\hline \multirow[b]{2}{*}{ Job categories } & \multicolumn{4}{|c|}{ Simulated Policy Scenarios } \\
\hline & $\begin{array}{l}\text { OECD minimum } \\
\text { import tariffs on } \\
\text { intermediate goods } \\
\text { and no LCRs }\end{array}$ & $\begin{array}{l}\text { OECD minimum } \\
\text { import tariffs } \\
\text { and no LCRs }\end{array}$ & $\begin{array}{c}\text { Zero-rating } \\
\text { of exports }\end{array}$ & $\begin{array}{c}\text { Full } \\
\text { liberalisation }\end{array}$ \\
\hline \multicolumn{5}{|c|}{ Change in employment (\%) } \\
\hline Technicians & 0.71 & 0.56 & 1.15 & 1.84 \\
\hline Officials and Managers & 0.72 & 0.56 & 1.22 & 1.92 \\
\hline Clerks & 0.59 & 0.44 & 0.92 & 1.47 \\
\hline Service/Shop workers & 0.56 & 0.46 & 0.78 & 1.31 \\
\hline Agriculture and unskilled & 0.60 & 0.63 & 0.80 & 1.53 \\
\hline Total & 0.61 & 0.53 & 0.89 & 1.53 \\
\hline \multicolumn{5}{|c|}{ Change in number of workers (millions) } \\
\hline Technicians & 0.06 & 0.05 & 0.10 & 0.16 \\
\hline Officials and Managers & 0.09 & 0.07 & 0.16 & 0.25 \\
\hline Clerks & 0.06 & 0.04 & 0.09 & 0.14 \\
\hline Service/Shop workers & 0.20 & 0.16 & 0.27 & 0.46 \\
\hline Agriculture and unskilled & 0.18 & 0.19 & 0.24 & 0.46 \\
\hline Total & 0.59 & 0.51 & 0.86 & 1.47 \\
\hline
\end{tabular}

(Source) Model results.

Trade liberalisation increases employment irrespective of whether the policies are reformed on either the import or export side or on both sides. Full trade liberalisation increases employment in most sectors, but there is some reallocation between sectors. Employment decreases in textiles and wearing apparel, electric equipment, machinery, and other manufacturing. The largest employment increase occurs in sectors that are not directly affected by trade policies, that is, not subjected to tariffs or export taxes, but sectors that benefit from higher overall production activity and are labour intensive. These sectors are trade business services and construction that together account for over $50 \%$ of the new created jobs.

Household income is higher in all simulations, the largest gains being reaped under the full liberalisation scenario (Table 1). Factor incomes are higher for all five labour 
categories in the model as well as for capital, land, and natural resources. ${ }^{9}$ Owners of land and natural resources experience the largest income gains of $4 \%$ and $10 \%$, respectively, when all trade barriers are eliminated. Income of unskilled workers increases less than that of skilled workers (by $1 \%$ and $1.5 \%$, respectively). Revenues on capital increase by less than labour income, $0.8 \%$. However, the distributional effects from trade liberalisation are not clear: while owners of land clearly benefit from liberalisation, poorer households that are likely to be more affected by unemployment and are composed of low-skilled labour benefit from increasing employment. While income from high-skilled workers increases more, higher income households are also likely to receive a larger part of income from returns from capital where the effects are lower.

\section{Adjustment costs}

Trade liberalisation changes the structure of the economy, and this adjustment process takes time. In the short term, there are frictions in adjusting to the changed factor demand and consumption patterns. Figure 8 presents the effects of a trade liberalisation shock in the short term where labour and capital are immobile and government consumption and investment are predefined. In the short-run scenario, imports and exports respectively increase by $15 \%$ and $17 \%$ less than in the medium-long run full liberalisation scenario. Brazilian production can realise only one quarter of its increase, while households' income only increases by half that of the medium-long term. These differences are mainly driven by restricted resource reallocation in the short term and show the importance of flexible factor markets for the full realisation of trade liberalisation benefits. Despite increasing wages in the booming sectors following the impossibility of absorbing unemployed workers, the effects on household income are less positive in the short run compared with the medium and long runs, as workers from shrinking economic sectors are not able to relocate to other sectors.

\footnotetext{
${ }^{9}$ Detailed results on factor income gains are available upon request by the authors.
} 


\section{Figure 8. Short-term effects}

(Full liberalisation scenario)

(\% change to the base)

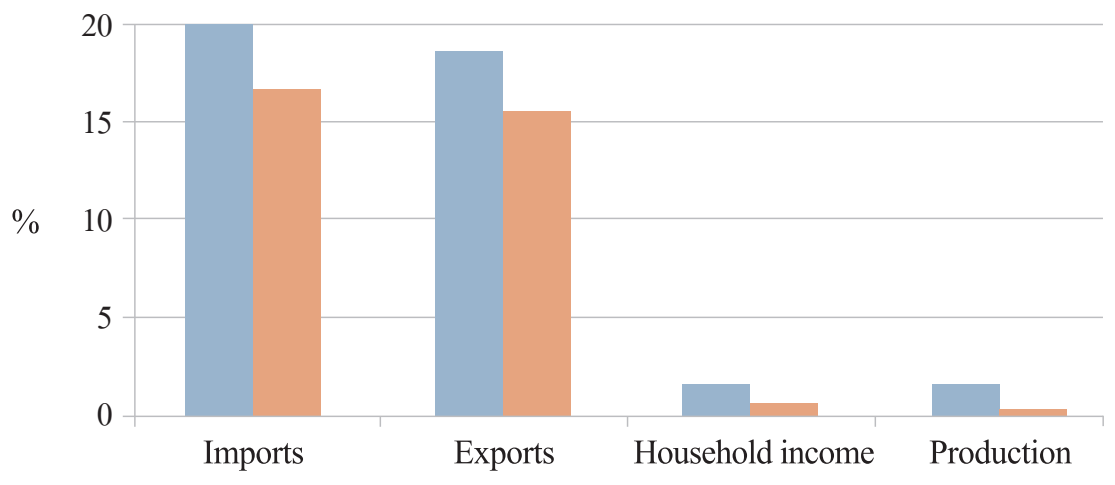

Medium-long term standard closure

- Short term closure

(Note) Standard closure as defined in section III. C; short term closure assumes immobile labour and capital and predefined government consumption and investment.

(Source) Model results.

\section{Sensitivity Analysis}

\section{A. Trade elasticities}

This study departs from the METRO database - and GTAP - as it specifies higher elasticities of substitution between imports from different regions and between aggregate imports and domestic production. Indeed, GTAP elasticities are implausibly low and have been rejected by Liu et al. (2002) in a back-casting exercise using a simplified version of the GTAP model.

Moreover, GTAP elasticity estimates have been computed using 1994 trade data (Hertel et al. 2004, Hummels 1999), since that time, the trade landscape has been marked by ongoing important advances in transportation and communication technologies, which led to the so-called "second unbundling," a further slicing of production processes 
into global value chains and intensified international trade flows (Baldwin 2006). In addition, since the 1990s, Brazil was undergoing a process of trade liberalisation, which opened-up the economy to some extent.

\section{Figure 9. Stability of model output to trade elasticities}

\section{A. GDP}

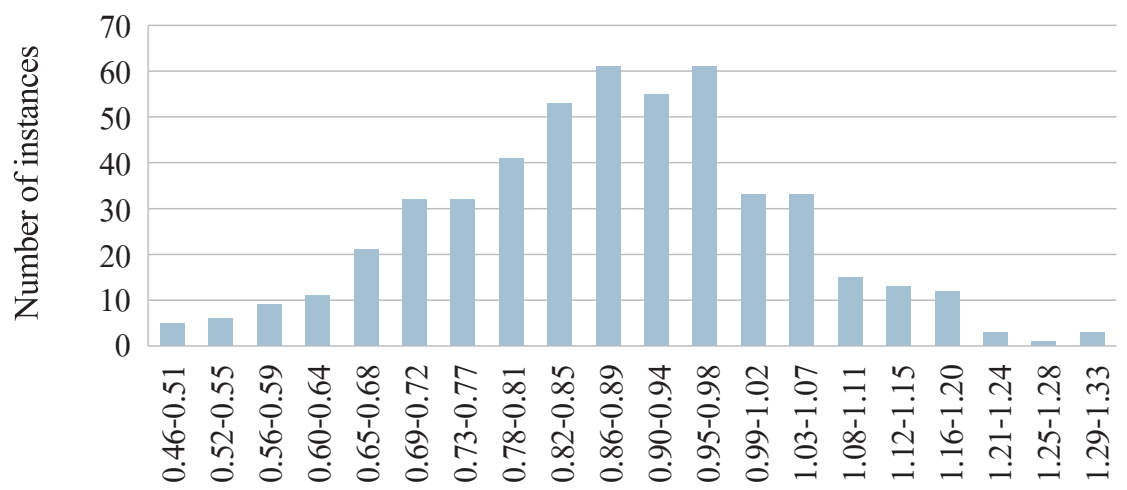

$\%$

B. Exports

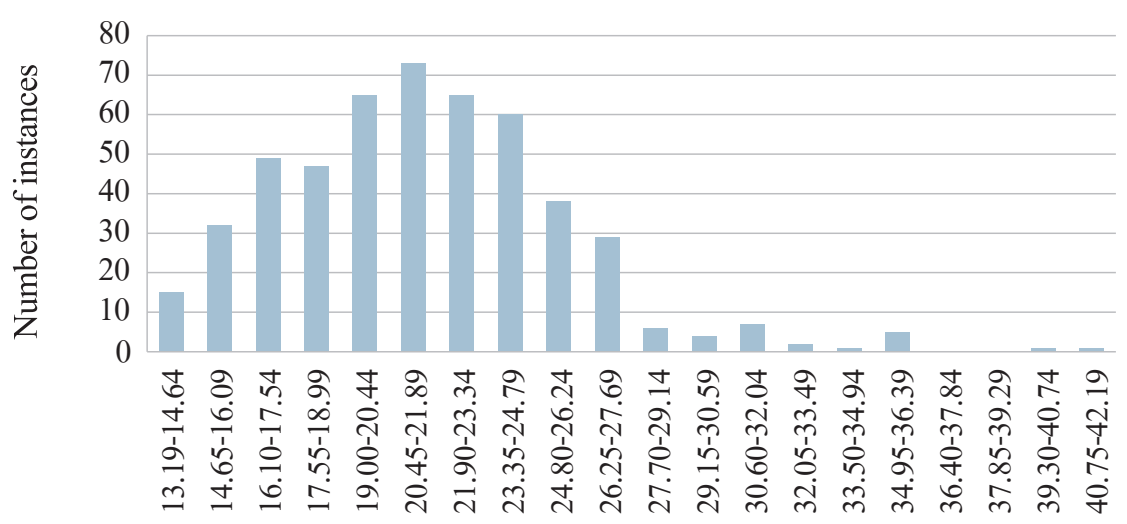




\section{Imports}

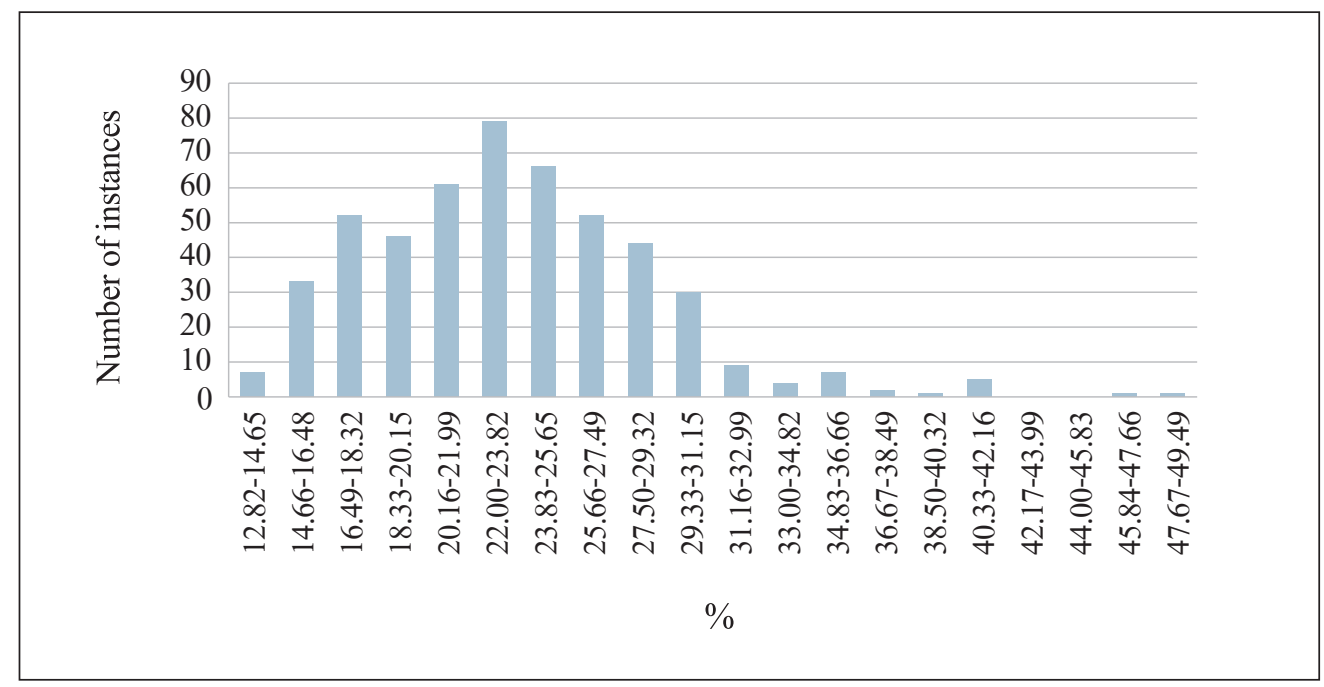

(Note) Number of instances where variables are in specific interval; full liberalisation scenario run 500 times with randomly drawn trade elasticities in the interval between 0.5 and 14 .

(Source) Model results.

Harrison et al. (2004) study the effects on the Brazilian economy of different policy options under the Mercosur trade negotiations using significantly higher elasticities. Their choice of elasticities finds some support in the estimates of Riedel (1988) and Athukorala and Riedel (1994) and produces results for terms of trade changes that are closer to the results of Chang and Winters (2002). ${ }^{10}$ At the same time, Harrison et al. (2004) focus on a long adjustment period of about 10 years, while in this study, the time horizon for the adjustment to policy shocks is assumed to be about three to five years. For this reason, this study adopts an intermediate choice and doubles the elasticities of substitution between imports from different regions and those between aggregate imports and domestic production. With respect to the original GTAP values, these elasticities are about two times higher, but they are still about three times lower than those used by Harrison et al. (2004); thus, they remain a conservative choice for the ease of substitutability between foreign suppliers and between foreign suppliers and domestic production, even in a fairly closed economy such as Brazil. The cautious estimates in this study are justified due to the considerable uncertainty around the values of trade

\footnotetext{
${ }^{10}$ In Harrison et al. (2004) the elasticity of substitution between imports from different regions is assumed to be 30 , and the higher level elasticity between aggregate imports and domestic production is assumed to be 15. Unlike Harrison et al. (2004), the elasticities in our study are sector specific.
} 
elasticities.

Given the uncertainty regarding the choice of trade elasticities, the robustness of the model results is tested with a thorough sensitivity analysis. ${ }^{11}$ For this purpose, the full liberalisation scenario is run 500 times with randomly drawn trade elasticities in the interval between 0.5 and $14 .^{12}$ The elasticities are sector specific and two rules are applied: each region faces the same trade elasticities on the import and export sides, and the relationship between the nesting levels is maintained. ${ }^{13}$

Figure 9 plots the range and number of instances for the selected macroeconomic variables for Brazil, that is, GDP, imports, and exports, for the full liberalisation scenario. The results show a stable outcome wherein results are concentrated around the mean ( $0.88 \%$ in GDP, $23.5 \%$ in imports, and $21.5 \%$ in exports): The minimum and maximum effects in GDP deviate about 50\% from the mean, and two-thirds of the results deviate less than $5 \%$ from the mean.

With the elasticities employed in this study (double standard GTAP), imports increase by $19.98 \%$ and exports increase by $18.75 \%$ in the full liberalisation scenario (Table 1 ). These outcomes can be found in the fourth decile of the possible outcomes and are thus below the mean. This indicates that the study's outcomes cannot be considered extreme, despite the deviation from GTAP elasticities.

\section{B. Flexible wages}

The analysis so far assumed unemployment in all labour categories in Brazil, taking the unemployment figures from Instituto Brasileiro de Geografia $e$ Estatística (IBGE). Alternatively, when factors are assumed as fully employed, wages are flexible to reflect factor demand. Trade and all other effects are slightly smaller with full employment compared with the standard setting with unemployment (Table 3). With full employment, expanding sectors now need to source workers from other sectors, and wages increase in the booming sectors to attract workers. Accordingly, the price decrease from lower input prices is dampened through increasing wages (wages increase by $0.4-0.6 \%$ ).

\footnotetext{
${ }^{11}$ We are grateful to Hannah Schürenberg-Frosch (2015) who shared the methodology and code for this exercise.

${ }^{12}$ This interval includes the typical range of Armington elasticities (0.1 3) up to an interval proposed in several CGE studies (9 18; Schürenberg-Frosch 2015). The borders are narrowed due to computational issues.

${ }^{13}$ We follow the generally applied setup for nested CES functions wherein elasticities are doubled on lower levels. This is done in order to maintain normal behaviour in the relationships.
} 


\section{Capital markets}

The standard closure follows the so-called Keynesian approach with investmentdriven savings. Investment is defined as fixed share of domestic final demand; government savings do not change, and households adjust the amount they save to investment demand. Alternatively, this assumption can be changed into a more neoclassical view, where the economy is savings driven. Results show that the specification of this assumption does not influence the model results (Table 3 ).

\section{Government account}

Government income is assumed as flexible in the standard closure, with the income tax balancing the income and expenditure differences and thus directly bouncing all possible budgetary effects directly on households. This closure choice has the advantage of not directly introducing sectoral biases in the model outcome. However, the closure choice might overestimate the burden on households.

When government income is predefined with inflexible tax rates, welfare effects are larger than income effects and significantly larger than in the standard closure. With fixed income, government expenditure needs to adjust to maintain the internal balance. As trade liberalisation reduces government income from import tariffs and indirect taxes, overall government income decreases and so does government expenditure, by $-3.2 \%$. This, in turn, has a strong effect on government activity, which is concentrated nearly exclusively in government services, a highly labour-intensive sector that does not directly profit from trade liberalisation. The consumption increase of households is not strong enough to overcome the negative effect, and effects are smaller compared with the standard closure. It is worth noting that trade effects are not affected by this closure swap, and the differences are related purely to internal reallocation and efficiency.

\section{E. Exchange rate and current account}

The model employs an exchange rate that allows for adjustments to relative income levels between regions. Together with the balance of the current account, this exchange rate defines the foreign exchange market. When the current account balance is fixed, as 
in the standard closure, the exchange rate adjusts to the relative income levels between regions. In the real world, or in a dynamic model, changes in the current account imply transfers between periods. In a static model, this mechanism is not available, and when the current balance is flexible, this would mean either getting or giving something away for free to the rest of the world. Table 3 shows this effect: a strong increase in imports is matched with a relatively small increase in exports. The size of this export effect can be interpreted as the pure cost reduction effect. To finance the current account balance deficit, which increases by $53 \%$, foreign investment flows into Brazil increase investment in Brazil by $9.8 \%$. As a result, domestic production increases, households are better off, and GDP increases stronger than before. Again, it is important to notice that this effect is not governed through some type of interest rate and that there is no mechanism of inter-temporal transfers in the static model. This scenario is thus likely to overestimate the benefits from trade liberalisation. The standard closure surely depicts a more conservative scenario, and even this conservative simulation shows the overall beneficial effects.

Table 3. Macroeconomic effects for different economic assumptions

(Full liberalisation scenario, \% changes to the base)

\begin{tabular}{|l|c|c|c|c|c|}
\hline & $\begin{array}{c}\text { Base } \\
\text { closure }\end{array}$ & $\begin{array}{c}\text { Full } \\
\text { employment }\end{array}$ & $\begin{array}{c}\text { Fixed } \\
\text { savings rate }\end{array}$ & $\begin{array}{c}\text { Fixed } \\
\text { government } \\
\text { income }\end{array}$ & $\begin{array}{c}\text { Fixed } \\
\text { exchange } \\
\text { rate }\end{array}$ \\
\hline Exports & 18.75 & 18.07 & 18.76 & 18.72 & 13.64 \\
\hline Imports & 19.98 & 19.31 & 19.99 & 19.94 & 25.60 \\
\hline Household Income & 1.62 & 0.67 & 1.62 & 1.12 & 2.27 \\
\hline Production & 1.74 & 0.83 & 1.74 & 1.38 & 2.13 \\
\hline Investment & 2.13 & 1.14 & 2.20 & 1.73 & 9.87 \\
\hline Investment Price Index & -1.41 & -1.54 & -1.40 & -1.44 & -1.34 \\
\hline Producer Price index & -0.03 & -0.01 & -0.03 & -0.03 & 0.01 \\
\hline
\end{tabular}




\section{Conclusion}

Compared to other countries, the Brazilian economy remains relatively closed. Moreover, as documented in this paper, trade protectionism has increased recently as policymakers attempted to reinforce the contribution of manufacturing in production, promote technological upgrades, and boost export competitiveness in manufacturing goods. However, manufacturing productivity in Brazil is low and stagnant compared with other emerging economies. Moreover, in spite of trade protection, the industry share in total value-added is small relative to other emerging economies and has even declined in recent years.

In view of the high trade barriers and recent increase in protection in Brazil, this study aims to quantify the impact of an unilateral policy of trade liberalisation that would act on three important policy channels: tariffs on imports, LCRs, and indirect taxes levied on exports. The model results convey a powerful message: trade protection, rather than support for industrial development and export competitiveness, is actually detrimental to achieving those objectives. The benefits stemming from lower barriers to trade on the efficiency of the economy are clear: LCRs and import tariffs limit the sourcing options of Brazilian producers, making intermediate inputs and capital goods more expensive, thus hampering cost competiveness.

Lowering barriers to trade allows firms to use a higher share of foreign intermediate goods in production. The major winners are manufacturing sectors, which manage to increase production by $2.6 \%$ in case of full liberalisation. In addition, production in the primary and tertiary sectors would increase as well. Manufacturing sectors benefit especially from liberalisation on the export side, that is, by eliminating indirect taxes levied on exports. There would be positive employment effects across all labour categories, and in absolute terms, especially in low-skilled occupations. A large part of these positive employment effects stems from increased overall demand and occur in sectors that are not directly affected by trade policies, such as service sectors.

Final goods are, in turn, sold at lower prices, enhancing the competitiveness of Brazilian exports and also benefitting Brazilian households. Lower barriers to trade would also reduce the unitary cost of capital, spurring investment and supporting further expansion of production going forward.

Although the economic effects on the overall economy are positive, it is important to identify the winners and losers at the sectoral level in order to devise policies that 
facilitate resource mobility, in particular labour. Since the gains from lifting impediments to trade can only be reaped if the economy is flexible enough to smoothen the structural adjustment that follows trade liberalisation, specific training programmes should be put in place for workers in industries whose outputs would shrink after trade liberalisation. For instance, the model estimates that the textile industry would lose about $10 \%$ of its output in the case of implementation of the full liberalisation scenario. As this industry is highly concentrated, the potential to create depressed and underdeveloped areas is nonnegligible. Training programmes could include transferability of skills to other sectors, and skill upgrades could also be complemented by income support programmes or programmes to facilitate regional mobility. On the other hand, one sector registering the largest gains is transportation, which also has the potential to absorb workers.

From a trade policy standpoint, the analysis in this study only considers unilateral reduction of trade barriers. In reality, however, Brazil could use its own trade liberalisation to negotiate improvements in market access for its exporters, which could further strengthen the effects of lower trade barriers on exports and production. Taking these points together, the overall expected benefits from a comprehensive trade liberalisation agenda are likely to significantly exceed those estimated by the model.

This observation applies more generally to Latin American countries, which have lower participation in GVCs and weak intra-regional linkages (e.g., Blyde 2014, OECD 2015c). GVC participation is limited to the supply of inputs based on relatively unprocessed natural resources, and trade is concentrated around a small number of products and markets, leaving many Latin American countries particularly vulnerable to external shocks. In addition, in a world where competitiveness is linked to competitively priced intermediate inputs, missing integration allegedly held back development of innovation and employment-intensive activities.

Received 11 February 2017, Revised 2 May 2017, Accepted 4 May 2017 


\section{References}

Athukorala, Premachandra and James Riedel, "Demand and Supply Factors in the Determination of NIE Exports: a simultaneous error-correction model for Hong Kong: A comment", Economic Journal 104-427 (1994): 1411-1414.

Baldwin, Richard, "Globalisation: the great unbundling(s)", Globalisation Challenges for Europe, Secretariat of the Economic Council, Finnish Prime Minister's Office, Helsinki, 2006.

Baumann, Renato and Honorio Kume, "Novos Padrões de Comércio e Política Tarifária no Brasill”. In O Futuro da Indústria no Brasil: desindustrialização em debate, edited by Bacha, Edmar and Monica Baumgarten de Bolle. Editora Civilização Brasileira, Rio de Janeiro, 2013.

Blyde, Juan S., Synchronized Factories: Latin America and the Caribbean in the Era of Global Value Chains, Springer, 2014.

Carneiro, Francisco and Jorge Arbache, "The Impacts of Trade on the Brazilian Labor Market: A CGE Model Approach". World Development 31-9 (2003): 1581-1595.

Castilho, Marta, Ana Ruiz, Karla de Souza, Julia Torraca and Leonardo Thuler, "A Estrutura Recente da Proteção Nominal e Efectiva no Brasil", Estudo preparado para a Fiesp e para o IEDI, Grupo de Indústria e Competitividade, Instituto de Economia, Universidade Federal do Rio de Janeiro, April, 2015.

Chang, Won and L. Alan Winters. "How Regional Blocs Affect Excluded Countries: the price effects of Mercosur", American Economic Review 92-4 (2002): 889-904.

De Siqueira, Rozane, Jose Ricardo Nogueira and Evaldo de Souza, “Alíquotas Efectivas e a Distribuição da Carga Tributária Indirecta entre as Famílias no Brasil”, Tópicos Especiais de Finanças Públicas, Finanças Públicas, XV Prêmio Tesouro Nacional, 2010.

Harrison, Glenn W., Thomas F. Rutherford, David G. Tarr, and Angelo Gurgel, "Trade Policy and Poverty Reduction in Brazil", The World Bank Economic Review 18-3 (2004): 289-317.

Hay, Donald A., "The Post 1990 Brazilian Trade Liberalization and the Performance of Large Manufacturing Firms: Productivity, Market Share and Profits", Texto para Discussão, No. 523, Instituto de Pesquisa Econômica Aplicada (IPEA), Rio de Janeiro, 
October, 1997.

Hertel, Thomas, David Hummels, Maros Ivanic and Roman Keeney, "How Confident Can We Be in CGE-Based Assessments of Free Trade Agreements?", NBER Working Paper 10477, 2004. Accessed May 2, 2017. http://www.nber.org/papers/w10477.

Hufbauer, Gary Clyde, Jeffrey J. Schott, Cathleen Cimino-Isaacs, Martin Vieiro and Erika Wada, Local Content Requirements: A Global Problem. Washington: The Peterson Institute for International Economic, 2013.

Hummels, David, "Towards a geography of Trade Costs", GTAP Working Paper 17, Center for Global Trade Analysis, Purdue University, West Lafayette, IN, 1999.

Liu, Jing, Channing Arndt and Thomas Hertel, "Parameter Estimation and Measures of Fit in a Global, General Equilibrium Model", Journal of Economic Integration, 19-3 (2001), p. 626-649.

Mattos, César (2013), Análise do Plano Brasil Maior, Nota Técnica, Consultoria Legislativa, Câmara dos Deputados, Brasília.

McDonald, Scott and Karen E. Thierfelder, Globe v2: A SAM Based Global CGE Model using GTAP Data. Model documentation, 2013. Accessed at May 2, 2017. http://www. cgemod.org.uk/.

Mendes, Marcos, Por que o Brasil Cresce Pouco? Desigualdade, Democracia e Baixo Crescimento no País do Futuro, Elsevier, Rio de Janeiro, 2014.

Narayanan, Badri .G., Angel Aguiar and Robert McDougall (eds.), Global Trade, Assistance, and Production: The GTAP 8 Data Base. Center for Global Trade Analysis, Purdue University, 2012. Accessed at May 2, 2017. https://www.gtap.agecon.purdue. edu/databases/v9/v9_doco.asp

OECD, Interconnected Economies: Benefiting from Global Value Chains, OECD Publishing, Paris, 2013. http://dx.doi.org/10.1787/9789264189560-en

OECD, Emerging Policy Issues: Localisation Barriers to Trade, OECD Publishing, Paris, 2014. DOI: $\underline{10.1787 / 18166873}$

OECD, OECD Economic Surveys: Brazil 2015, OECD Publishing, Paris, 2015a. http:// dx.doi.org/10.1787/eco_surveys-bra-2015-en

OECD, METRO version 1 model documentation, Trade and Agriculture Directorate, 
OECD Publishing, January, 2015b. Accessed at May 2, 2017. http:/www.oecd.org/ officialdocuments/publicdisplaydocumentpdf/?cote=TAD/TC/WP\%282014\%2924/ FINAL\&docLanguage $=$ En

OECD, Latin American Economic Outlook, Chapter 4, OECD Publishing, 2015c.

Reis, Cristina and Julio de Almeida, "A Inserção do Brasil nas Cadeias Globais de Valor Comparativamente aos BRIICS", Texto para Discussão, Instituto de Economia UNICAMP, Campinas, No. 233, 2014. Accessed at May 2 , 2017. https://www.google. fr/url? sa $=$ t\&rct $=\mathrm{j} \& \mathrm{q}=\&$ esrc $=$ s\&source $=$ web $\& \mathrm{~cd}=1 \& \mathrm{cad}=$ ja\& $\&$ uact $=8 \&$ ved $=0$ ahUKE wiz3fSco9HTAhXDWhoKHZxSDE0QFggmMAA\&url=http\%3A\%2F\%2Fwww.eco. unicamp.br\%2Fdocprod\%2Fdownarq.php\%3Fid\%3D3347\%26tp\%3Da\&usg=AFQjCN HIOaWUrl_--mY-IVeCRGWoPMxIUg

Riedel, James, "The Demand for LDC Exports of Manufactures: Estimates from Hong Kong”, Economic Journal, 98-389 (1988): 138-148.

Schürenberg-Frosch, Hannah, "We could not care less about Armington elasticities - but should we? A meta-sensitivity analysis of the influence of Armington elasticity misspecification on simulation results", Ruhr Economic Papers 594 (2015). ISBN 9783-86788-689-5, http://dx.doi.org/10.4419/86788689

Thorstensen, Vera and Lucas Ferraz, Uma Nova Agenda para a Política de Comércio Exterior do Brasil. Instituto de Estudos para o Desenvolvimento Industrial (IEDI), São Paulo, 2015. Accesed at May 2, 2017. http://www.iedi.org.br/anexos legado/ 557b97922ae546bb.pdf.

Vieira, L. and P. Mourão (2015), “A Imunidade Tributária do ICMS sobre Exportações”, Revista Tributária e de Finanças Públicas, 120 (2015): 73-91. 


\section{Appendix 1: Regions, sectors and production factors}

\begin{tabular}{|c|c|c|c|}
\hline Regions & \multicolumn{2}{|c|}{ Sectors } & Factors \\
\hline Brazil & Agriculture & Electronic equipment & Labour: \\
\hline Latin America & Coal & $\begin{array}{l}\text { Machinery and } \\
\text { equipment }\end{array}$ & $\begin{array}{l}\text { Officials and } \\
\text { Managers }\end{array}$ \\
\hline North America & Oil & Manufactures nec. & Technicians \\
\hline OECD Asia & Gas & Electricity & Clerks \\
\hline $\begin{array}{l}\text { Non-OECD } \\
\text { East Asia }\end{array}$ & Minerals & Gas distribution & $\begin{array}{l}\text { Service/Shop } \\
\text { workers }\end{array}$ \\
\hline $\begin{array}{l}\text { Emerging South } \\
\text { East Asia }\end{array}$ & Food products & Water & $\begin{array}{l}\text { Agricultural } \\
\text { and unskilled }\end{array}$ \\
\hline OECD EU & Textiles & Construction & Capital \\
\hline Rest of the world & Wearing apparel & Trade & Land \\
\hline & Leather products & Other transport & $\begin{array}{l}\text { Other natural } \\
\text { resources }\end{array}$ \\
\hline & Wood products & Sea transport & \\
\hline & Paper prod., publishing & Air transport & \\
\hline & Petroleum, coal prod. & Communication & \\
\hline & $\begin{array}{l}\text { Chemical, rubber } \\
\text { and plastic products }\end{array}$ & Financial services & \\
\hline & Mineral products & Insurance & \\
\hline & Ferrous metals & Business services & \\
\hline & Metals & $\begin{array}{l}\text { Recreation and } \\
\text { oth. services }\end{array}$ & \\
\hline & Metal products & $\begin{array}{l}\text { Other services } \\
\text { (Government) }\end{array}$ & \\
\hline & $\begin{array}{l}\text { Motor vehicles } \\
\text { and parts }\end{array}$ & Dwellings & \\
\hline & Transport equipment & & \\
\hline
\end{tabular}




\section{Appendix 2: Production quantities by sector}

( $\%$ change to the base)

\begin{tabular}{|c|c|c|c|c|c|}
\hline & \begin{tabular}{|c} 
OECD \\
minimum \\
import tariffs \\
on intermediate \\
goods and no \\
LCRs
\end{tabular} & $\begin{array}{c}\text { OECD } \\
\text { minimum } \\
\text { import tariffs } \\
\text { and no LCRs }\end{array}$ & $\begin{array}{l}\text { Zero-rating } \\
\text { of exports }\end{array}$ & $\begin{array}{c}\text { Full } \\
\text { liberalisation }\end{array}$ & $\begin{array}{c}\text { Adopting } \\
\text { Chile's } \\
\text { trade } \\
\text { policy }\end{array}$ \\
\hline Agriculture & 1.23 & 1.85 & -0.94 & 0.75 & 0.40 \\
\hline Oil & 0.97 & 1.46 & -1.16 & 0.32 & 1.71 \\
\hline Gas & 1.47 & 3.02 & -8.48 & -7.42 & -16.97 \\
\hline Minerals & 2.28 & 3.52 & 3.42 & 7.22 & 5.73 \\
\hline Food products & 1.48 & 1.81 & -0.80 & 0.83 & 0.41 \\
\hline Textiles & -8.92 & -9.65 & 0.46 & -9.61 & -6.76 \\
\hline Wearing apparel & 1.86 & -1.49 & 0.52 & -1.07 & -1.08 \\
\hline Leather products & 7.38 & 4.09 & 11.53 & 18.95 & 17.77 \\
\hline Wood products & 3.27 & 5.77 & 4.00 & 10.26 & 8.72 \\
\hline $\begin{array}{l}\text { Paper products, } \\
\text { publishing }\end{array}$ & 0.38 & 0.96 & 2.26 & 3.45 & 2.78 \\
\hline $\begin{array}{l}\text { Petroleum, } \\
\text { coal products }\end{array}$ & 0.54 & 0.55 & 1.91 & 2.60 & 0.69 \\
\hline $\begin{array}{l}\text { Chemicals, rubber, } \\
\text { plastic prod. }\end{array}$ & -2.01 & -1.64 & 0.59 & -1.06 & -1.46 \\
\hline Mineral products & 0.33 & 1.01 & 3.02 & 4.32 & 3.78 \\
\hline Ferrous metals & 1.09 & 0.46 & 6.77 & 8.27 & 7.08 \\
\hline Non-ferrous metals & 8.02 & 13.44 & 8.01 & 23.71 & 19.41 \\
\hline Metal products & -2.62 & -3.63 & 2.82 & -0.66 & -1.01 \\
\hline $\begin{array}{l}\text { Motor vehicles } \\
\text { and parts }\end{array}$ & -0.05 & 0.53 & 7.11 & 8.94 & 8.22 \\
\hline Transport equipment & 12.08 & 15.11 & 5.72 & 22.91 & 19.64 \\
\hline Electronic equipment & -1.85 & -3.16 & 2.18 & -0.66 & -0.66 \\
\hline $\begin{array}{l}\text { Machinery and } \\
\text { equipment }\end{array}$ & 3.43 & -6.94 & 4.66 & -1.05 & -1.99 \\
\hline Other manufactures & 0.54 & -2.75 & 0.80 & -2.14 & -2.43 \\
\hline Electricity & 1.45 & 2.00 & 1.79 & 4.16 & 3.22 \\
\hline $\begin{array}{l}\text { Gas manufacture } \\
\text { distribution }\end{array}$ & 1.41 & 1.88 & 2.06 & 4.32 & 2.83 \\
\hline
\end{tabular}


(continued)

\begin{tabular}{|l|c|c|c|c|c|}
\hline & $\begin{array}{c}\text { OECD } \\
\text { minimum } \\
\text { import tariffs } \\
\text { on intermediate } \\
\text { goods and no } \\
\text { LCRs }\end{array}$ & $\begin{array}{c}\text { OECD } \\
\text { minimum }\end{array}$ & Znport tariffs \\
and no LCRs & $\begin{array}{c}\text { Zero-rating } \\
\text { of exports }\end{array}$ & $\begin{array}{c}\text { Full } \\
\text { liberalisation }\end{array}$ & $\begin{array}{c}\text { Adopting } \\
\text { Chile's } \\
\text { trade } \\
\text { policy }\end{array}$ \\
\hline Water & 0.56 & 0.32 & 0.98 & 1.41 & 0.99 \\
\hline Construction & 0.61 & 0.99 & 0.94 & 2.02 & 1.65 \\
\hline Trade & 0.61 & 0.39 & 0.91 & 1.41 & 1.02 \\
\hline Other transport & 0.79 & 0.58 & 1.06 & 1.76 & 1.17 \\
\hline Sea transport & 3.34 & 5.38 & -2.35 & 2.57 & 1.13 \\
\hline Air transport & 1.37 & 1.54 & 0.06 & 1.67 & 0.78 \\
\hline Communication & 0.73 & 0.47 & 0.77 & 1.32 & 0.95 \\
\hline Financial services & 0.59 & 0.29 & 0.85 & 1.24 & 0.86 \\
\hline Insurance & 0.47 & 0.33 & 0.34 & 0.69 & 0.39 \\
\hline Business services & 1.39 & 1.75 & 0.04 & 1.82 & 1.31 \\
\hline $\begin{array}{l}\text { Recreation and } \\
\text { other services }\end{array}$ & 0.55 & 0.45 & 0.31 & 0.76 & 0.41 \\
\hline $\begin{array}{l}\text { Public Administration, } \\
\text { Defence, Health, } \\
\text { Education }\end{array}$ & 0.28 & 0.06 & 0.47 & 0.53 & 0.26 \\
\hline
\end{tabular}




\section{Appendix 3: Effects on exports by sector}

( $\%$ change to the base)

\begin{tabular}{|c|c|c|c|c|c|}
\hline & \begin{tabular}{|c} 
OECD \\
minimum \\
import tariffs \\
on intermediate \\
goods and no \\
LCRs \\
\end{tabular} & $\begin{array}{c}\text { OECD } \\
\text { minimum } \\
\text { import tariffs } \\
\text { and no LCRs }\end{array}$ & $\begin{array}{c}\text { Zero-rating } \\
\text { of exports }\end{array}$ & $\begin{array}{c}\text { Full } \\
\text { liberalisation }\end{array}$ & $\begin{array}{c}\text { Adopting } \\
\text { Chile's } \\
\text { trade } \\
\text { policy }\end{array}$ \\
\hline Agriculture & 4.33 & 7.43 & -4.78 & 2.21 & 1.03 \\
\hline Oil & 2.12 & 3.57 & -6.50 & -3.35 & -8.41 \\
\hline Gas & -0.05 & -0.07 & -0.03 & -0.12 & -0.18 \\
\hline Minerals & 2.71 & 4.36 & 3.41 & 7.92 & 6.37 \\
\hline Food products & 6.28 & 10.48 & -6.37 & 3.08 & 1.60 \\
\hline Textiles & 5.57 & 10.50 & 9.09 & 19.95 & 19.13 \\
\hline Wearing apparel & 11.87 & 15.23 & 1.78 & 17.12 & 14.12 \\
\hline Leather products & 16.86 & 23.49 & 26.99 & 58.22 & 53.67 \\
\hline Wood products & 10.35 & 18.12 & 7.57 & 26.77 & 23.83 \\
\hline $\begin{array}{l}\text { Paper products, } \\
\text { publishing }\end{array}$ & 7.05 & 12.41 & 12.80 & 26.53 & 24.35 \\
\hline $\begin{array}{l}\text { Petroleum, } \\
\text { coal products }\end{array}$ & 1.47 & 2.36 & 7.56 & 10.04 & 4.82 \\
\hline $\begin{array}{l}\text { Chemicals, rubber, } \\
\text { plastic prod. }\end{array}$ & 6.38 & 11.65 & 5.15 & 16.99 & 14.53 \\
\hline Mineral products & 6.28 & 10.89 & 15.68 & 27.96 & 25.52 \\
\hline Ferrous metals & 7.71 & 11.86 & 15.46 & 29.40 & 26.30 \\
\hline Non-ferrous metals & 14.67 & 25.44 & 13.92 & 42.99 & 36.01 \\
\hline Metal products & 7.83 & 13.18 & 19.35 & 34.69 & 31.88 \\
\hline $\begin{array}{l}\text { Motor vehicles } \\
\text { and parts }\end{array}$ & 10.19 & 15.10 & 22.45 & 41.64 & 38.84 \\
\hline Transport equipment & 23.87 & 32.49 & 13.08 & 50.00 & 43.53 \\
\hline Electronic equipment & 13.84 & 19.00 & 30.48 & 55.38 & 51.32 \\
\hline $\begin{array}{l}\text { Machinery and } \\
\text { equipment }\end{array}$ & 13.57 & 15.06 & 18.27 & 37.08 & 33.17 \\
\hline Other manufactures & 9.19 & 13.29 & 9.42 & 23.45 & 21.09 \\
\hline Electricity & 6.31 & 11.24 & -6.03 & 4.30 & 2.45 \\
\hline $\begin{array}{l}\text { Gas manufacture } \\
\text { distribution }\end{array}$ & 0.46 & 0.75 & -0.60 & 0.06 & -0.21 \\
\hline
\end{tabular}


(continued)

\begin{tabular}{|l|c|c|c|c|c|}
\hline & $\begin{array}{c}\text { OECD } \\
\text { minimum } \\
\text { import tariffs } \\
\text { on intermediate } \\
\text { goods and no } \\
\text { LCRs }\end{array}$ & $\begin{array}{c}\text { OECD } \\
\text { minimum } \\
\text { import tariffs } \\
\text { and no LCRs }\end{array}$ & $\begin{array}{c}\text { Zero-rating } \\
\text { of exports }\end{array}$ & $\begin{array}{c}\text { Full } \\
\text { liberalisation }\end{array}$ & $\begin{array}{c}\text { Adopting } \\
\text { Chile's } \\
\text { trade } \\
\text { policy }\end{array}$ \\
\hline Water & 6.39 & 11.24 & -6.93 & 3.04 & 1.64 \\
\hline Construction & 3.02 & 5.23 & -2.66 & 2.18 & 1.52 \\
\hline Trade & 4.39 & 7.54 & -4.50 & 2.46 & 1.51 \\
\hline Other transport & 4.12 & 6.67 & -3.70 & 2.52 & 0.94 \\
\hline Sea transport & 5.37 & 9.42 & -5.61 & 2.80 & 0.88 \\
\hline Air transport & 3.77 & 6.23 & -3.91 & 1.87 & 0.12 \\
\hline Communication & 4.40 & 7.57 & -4.81 & 2.09 & 1.21 \\
\hline Financial services & 4.04 & 7.20 & -4.79 & 1.79 & 0.96 \\
\hline Insurance & 4.09 & 7.35 & -4.99 & 1.68 & 0.84 \\
\hline Business services & 4.83 & 8.50 & -5.23 & 2.51 & 1.54 \\
\hline $\begin{array}{l}\text { Recreation and } \\
\text { other services }\end{array}$ & 5.67 & 10.02 & -6.14 & 2.85 & 1.63 \\
\hline $\begin{array}{l}\text { Public Administration, } \\
\text { Defence, Health, } \\
\text { Education }\end{array}$ & 6.35 & 11.78 & -7.30 & 2.89 & 1.60 \\
\hline
\end{tabular}




\section{Appendix 4: Effects on imports by sector}

( $\%$ change to the base)

\begin{tabular}{|c|c|c|c|c|c|}
\hline & $\begin{array}{c}\text { OECD } \\
\text { minimum } \\
\text { import tariffs } \\
\text { on intermediate } \\
\text { goods and no } \\
\text { LCRs }\end{array}$ & $\begin{array}{c}\text { OECD } \\
\text { minimum } \\
\text { import tariffs } \\
\text { and no LCRs }\end{array}$ & $\begin{array}{l}\text { Zero-rating } \\
\text { of exports }\end{array}$ & \begin{tabular}{|c|} 
Full \\
liberalisation
\end{tabular} & $\begin{array}{l}\text { Adopting } \\
\text { Chile's } \\
\text { trade } \\
\text { policy }\end{array}$ \\
\hline Agriculture & 1.45 & 1.16 & 4.38 & 5.54 & 3.38 \\
\hline Oil & -1.31 & -2.39 & 8.05 & 5.80 & -11.83 \\
\hline Gas & -1.56 & -2.97 & 14.69 & 14.78 & 28.48 \\
\hline Minerals & -1.10 & -2.06 & 4.12 & 2.58 & 2.67 \\
\hline Food products & 4.35 & 14.54 & 6.94 & 22.78 & 17.20 \\
\hline Textiles & 59.61 & 56.28 & 7.83 & 67.63 & 49.25 \\
\hline Wearing apparel & -10.06 & 94.89 & 8.89 & 112.16 & 88.45 \\
\hline Leather products & 2.32 & 117.70 & 6.72 & 130.80 & 101.45 \\
\hline Wood products & 43.91 & 47.80 & 7.74 & 59.40 & 55.08 \\
\hline $\begin{array}{l}\text { Paper products, } \\
\text { publishing }\end{array}$ & 25.99 & 23.13 & 6.61 & 31.58 & 30.08 \\
\hline $\begin{array}{l}\text { Petroleum, } \\
\text { coal products }\end{array}$ & -0.27 & -0.89 & 2.85 & 2.14 & 3.02 \\
\hline $\begin{array}{l}\text { Chemicals, rubber, } \\
\text { plastic prod. }\end{array}$ & 13.40 & 13.03 & 6.91 & 21.15 & 19.36 \\
\hline Mineral products & 30.29 & 28.38 & 6.29 & 36.83 & 31.25 \\
\hline Ferrous metals & 30.15 & 22.15 & 7.79 & 32.72 & 28.64 \\
\hline Non-ferrous metals & 0.89 & -7.58 & 6.66 & -0.45 & 0.31 \\
\hline Metal products & 64.70 & 66.57 & 9.21 & 82.59 & 76.56 \\
\hline $\begin{array}{l}\text { Motor vehicles } \\
\text { and parts }\end{array}$ & 25.43 & 27.67 & 4.08 & 33.13 & 29.12 \\
\hline Transport equipment & 4.21 & 6.77 & 4.64 & 12.63 & 10.91 \\
\hline Electronic equipment & 18.40 & 24.41 & 7.89 & 34.47 & 30.43 \\
\hline $\begin{array}{l}\text { Machinery and } \\
\text { equipment }\end{array}$ & 2.64 & 25.86 & 4.46 & 30.83 & 29.17 \\
\hline Other manufactures & 8.23 & 86.94 & 8.92 & 103.91 & 100.09 \\
\hline Electricity & -4.46 & -7.98 & 8.06 & 0.04 & 0.89 \\
\hline $\begin{array}{l}\text { Gas manufacture } \\
\text { distribution }\end{array}$ & -2.00 & -3.38 & 4.63 & 1.46 & 2.59 \\
\hline
\end{tabular}


(continued)

\begin{tabular}{|l|c|c|c|c|c|}
\hline & $\begin{array}{c}\text { OECD } \\
\text { minimum } \\
\text { import tariffs } \\
\text { on intermediate } \\
\text { goods and no } \\
\text { LCRs }\end{array}$ & $\begin{array}{c}\text { OECD } \\
\text { minimum } \\
\text { import tariffs } \\
\text { and no LCRs }\end{array}$ & $\begin{array}{c}\text { Zero-rating } \\
\text { of exports }\end{array}$ & $\begin{array}{c}\text { Full } \\
\text { liberalisation }\end{array}$ & $\begin{array}{c}\text { Adopting } \\
\text { Chile's } \\
\text { trade } \\
\text { policy }\end{array}$ \\
\hline Water & -5.42 & -9.55 & 7.81 & -2.05 & -0.93 \\
\hline Construction & -4.22 & -6.75 & 4.89 & -1.95 & -1.04 \\
\hline Trade & -3.76 & -6.82 & 5.38 & -1.49 & -0.73 \\
\hline Other transport & -3.38 & -5.95 & 4.83 & -1.10 & 0.07 \\
\hline Sea transport & -2.43 & -4.73 & 4.22 & -0.04 & 0.74 \\
\hline Air transport & -2.53 & -4.84 & 4.10 & -0.64 & 0.53 \\
\hline Communication & -3.61 & -6.63 & 5.27 & -1.41 & -0.68 \\
\hline Financial services & -3.48 & -6.62 & 5.57 & -1.07 & -0.42 \\
\hline Insurance & -3.52 & -6.60 & 5.28 & -1.35 & -0.66 \\
\hline Business services & -3.56 & -6.57 & 5.26 & -1.32 & -0.59 \\
\hline $\begin{array}{l}\text { Recreation and } \\
\text { other services }\end{array}$ & -3.15 & -5.80 & 4.23 & -1.57 & -0.87 \\
\hline $\begin{array}{l}\text { Public Administration, } \\
\text { Defence, Health, } \\
\text { Education }\end{array}$ & -2.12 & -4.06 & 3.12 & -0.91 & -0.49 \\
\hline
\end{tabular}

